\title{
Ocean carbonate system variability in the North Atlantic Subpolar surface water (1993-2017)
}

\author{
Coraline Leseurre $^{1}$, Claire Lo Monaco ${ }^{1}$, Gilles Reverdin ${ }^{1}$, Nicolas Metzl ${ }^{1}$, Jonathan Fin $^{1}$, Solveig Olafsdottir ${ }^{2}$, and \\ Virginie Racapé ${ }^{3}$ \\ ${ }^{1}$ Laboratoire d'Océanographie et du Climat: Expérimentation et Approches Numériques (LOCEAN-IPSL), \\ Sorbonne Université-CNRS-IRD-MNHN, Paris, 75005, France \\ ${ }^{2}$ Marine and Freshwater Research Institute (MFRI), Reykjavík, Iceland \\ ${ }^{3}$ Laboratoire d'Océanographie Physique et Spatiale (LOPS), CNRS-IFREMER-IRD-UBO, Plouzané, 29280, France
}

Correspondence: Coraline Leseurre (coraline.leseurre@locean-ipsl.upmc.fr)

Received: 29 March 2019 - Discussion started: 5 April 2019

Revised: 30 March 2020 - Accepted: 2 April 2020 - Published: 14 May 2020

\begin{abstract}
The North Atlantic is one of the major ocean sinks for natural and anthropogenic atmospheric $\mathrm{CO}_{2}$. Given the variability of the circulation, convective processes or warming-cooling recognized in the high latitudes in this region, a better understanding of the $\mathrm{CO}_{2}$ sink temporal variability and associated acidification needs a close inspection of seasonal, interannual to multidecadal observations. In this study, we investigate the evolution of $\mathrm{CO}_{2}$ uptake and ocean acidification in the North Atlantic Subpolar Gyre (50-64 N) using repeated observations collected over the last 3 decades in the framework of the long-term monitoring program SURATLANT (SURveillance de l'ATLANTique). Over the full period (1993-2017) $\mathrm{pH}$ decreases $\left(-0.0017 \mathrm{yr}^{-1}\right)$ and fugacity of $\mathrm{CO}_{2}\left(f \mathrm{CO}_{2}\right)$ increases $\left(+1.70 \mu \mathrm{atm} \mathrm{yr} \mathrm{y}^{-1}\right)$. The trend of $f \mathrm{CO}_{2}$ in surface water is slightly less than the atmospheric rate $\left(+1.96 \mu \mathrm{atm} \mathrm{yr}^{-1}\right)$. This is mainly due to dissolved inorganic carbon (DIC) increase associated with the anthropogenic signal. However, over shorter periods (4-10 years) and depending on the season, we detect significant variability investigated in more detail in this study. Data obtained between 1993 and 1997 suggest a rapid increase in $f \mathrm{CO}_{2}$ in summer (up to $+14 \mu \mathrm{atm} \mathrm{yr}^{-1}$ ) that was driven by a significant warming and an increase in DIC for a short period. Similar $f \mathrm{CO}_{2}$ trends are observed between 2001 and 2007 during both summer and winter, but, without significant warming detected, these trends are mainly explained by an increase in DIC and a decrease in alkalinity. This also leads to a $\mathrm{pH}$ decrease but with contrasting trends depending on the region and season (between -0.006 and $-0.013 \mathrm{yr}^{-1}$ ). Con-
\end{abstract}

versely, data obtained during the last decade (2008-2017) in summer show a cooling of surface waters and an increase in alkalinity, leading to a strong decrease in surface $f \mathrm{CO}_{2}$ (between -4.4 and $-2.3 \mu$ atm $\mathrm{yr}^{-1}$; i.e., the ocean $\mathrm{CO}_{2}$ sink increases). Surprisingly, during summer, $\mathrm{pH}$ increases up to $+0.0052 \mathrm{yr}^{-1}$ in the southern subpolar gyre. Overall, our results show that, in addition to the accumulation of anthropogenic $\mathrm{CO}_{2}$, the temporal changes in the uptake of $\mathrm{CO}_{2}$ and ocean acidification in the North Atlantic Subpolar Gyre present significant multiannual variability, not clearly directly associated with the North Atlantic Oscillation (NAO). With such variability it is uncertain to predict the near-future evolution of air-sea $\mathrm{CO}_{2}$ fluxes and $\mathrm{pH}$ in this region. Thus, it is highly recommended to maintain long-term observations to monitor these properties in the next decade.

\section{Introduction}

The ocean plays an important role in climate regulation by absorbing between one-quarter and one-third of anthropogenic carbon dioxide $\left(\mathrm{CO}_{2}\right)$ emitted to the atmosphere (Le Quéré et al., 2018; Gruber et al., 2019). The North Atlantic (NA) is one of the strongest ocean sinks for natural (Takahashi et al., 2009) and anthropogenic atmospheric $\mathrm{CO}_{2}$ (Khatiwala et al., 2013; Sabine et al., 2004; Perez et al., 2008). Although many observational studies were conducted in the NA to evaluate how the $\mathrm{CO}_{2}$ sink varies from seasonal to multi-decadal scales and modeling studies attempted to 
reproduce the observed changes, there are still open questions regarding the processes that control the contemporary $\mathrm{CO}_{2}$ sink variability in this region (e.g., Schuster et al., 2013, for a synthesis). The uptake of $\mathrm{CO}_{2}$ in the NA is mainly due to extensive biological activity during spring-summer and considerable heat loss during winter, both processes being subject to significant spatiotemporal variability related to climate mode such as the North Atlantic Oscillation (NAO) and the Atlantic Multidecadal Variability (AMV), also called the Atlantic Multidecadal Oscillation (AMO). The recent decades have indeed witnessed large variations in the NAO index (Hurrell index, 2013), which displayed strong positive values in the early 1990s, tended to be positive from 1996 to the early 2000, and was then more neutral, albeit with extreme anomalies, such as the negative 2010 event, until again witnessing large positive anomalies in the mid2010s. The NA has also been at the core of large decadal to multi-decadal variability of the AMV with a positive peak by the mid-2000s and a decrease since then (Robson et al., 2018). In the North Atlantic Subpolar Gyre (NASPG, around $50-60^{\circ} \mathrm{N}$ ) where the oceanic $\mathrm{CO}_{2}$ sink is particularly strong (e.g., Watson et al., 2009), recent years in the mid-2010s have also witnessed particularly large negative surface temperature anomalies (Josey et al., 2018) and an extreme freshening (Holliday et al., 2020). Associated changes in the ocean circulation and water masses in the NASPG are for example presented in Chafik et al. (2014, 2019), Desbruyères et al. (2015) and Nigam et al. (2018). These physical processes linked to the NAO and/or AMV directly impact the sea surface $f \mathrm{CO}_{2}$ and air-sea $\mathrm{CO}_{2}$ fluxes through warming-cooling or deeper convection as this has been observed in the NASPG for specific periods (Corbière et al., 2007; Fröb et al., 2019). However, a direct link of the $\mathrm{CO}_{2}$ uptake variability with the NAO depends on the period investigated, and this is not always clearly revealed from observations (Metzl et al., 2010; Schuster et al., 2013).

Ocean models and Earth system models (ESMs) can help to understand the link between the NAO and biogeochemical cycles, but results from models in the NA are still controversial (Thomas et al., 2008; Ullman et al., 2009; Keller et al., 2012; Tjiputra et al., 2012). Keller et al. (2012) investigated simulations from six ESMs and found that the interannual variability of the $\mathrm{CO}_{2}$ sink in the North Atlantic is the largest in the subpolar gyre. They also conclude that for winter (i.e., not the productive season) on-site entrainment in the NASPG (mixing and upwelling) is the main driver of carbon sink variability as opposed to advection (Thomas et al., 2008), but the magnitude and responses of the carbon uptake to the NAO significantly differ between the ESMs (Keller et al., 2012). Thomas et al. (2008) suggest that negative or neutral NAO conditions result in a substantial decline of the $\mathrm{CO}_{2}$ uptake for the years 1997-2004 along the North Atlantic Current (NAC) region and in the eastern subpolar gyre. Conversely, Ullman et al. (2009) conclude that the $\mathrm{CO}_{2}$ uptake increased over 1992-2006. During the transition of the NAO (from positive to neutral), their model simulates a decline of the convection and vertical DIC supply to the surface in the subpolar region, counteracting the increase in $\mathrm{pCO}_{2}$ due to warming. This leads to a relatively small $\mathrm{pCO}_{2}$ increase compared with the atmospheric $\mathrm{CO}_{2}$ trend and an increasing $\mathrm{CO}_{2}$ sink, while observations in 1993-2003 suggest a reduced $\mathrm{CO}_{2}$ sink in the NASPG after the NAO shift in the mid-1990s (Corbière et al., 2007).

For longer timescales, 2 decades or more, observations in the NASPG show a gradual $f \mathrm{CO}_{2}$ increase slightly smaller or indistinguishable from trends in atmospheric $\mathrm{CO}_{2}$ and that the long-term oceanic $f \mathrm{CO}_{2}$ trend is not correlated with the NAO (Takahashi et al., 2009; McKinley et al., 2011; Fay and McKinley, 2013). On a decadal scale the link between the AMO and $f \mathrm{CO}_{2}$ variability in the NASPG appears more robust (Breeden and McKinley, 2016; Landschützer et al., 2019). When the AMO enters a positive phase, these studies indicate a reduction of DIC in the NASPG due to reduced mixing, a process that dominates the effect of warming on $f \mathrm{CO}_{2}$ (Breeden and McKinley, 2016). Consequently, since the mid-1990s the $f \mathrm{CO}_{2}$ long-term trend lagged the one in the atmosphere, and the $\mathrm{CO}_{2}$ uptake is increasing in this region. Such a signal is not captured by current ESM CMIP5 models (Tjiputra et al., 2014; Lebehot et al., 2019) likely due to inadequate representation of biogeochemical cycles (here DIC and/or TA) and in part to bad representation of mixing leading to $\mathrm{pCO}_{2}$ seasonality that is opposed to observations (Goris et al., 2018). This leads to uncertainties on the evolution of the oceanic $\mathrm{CO}_{2}$ uptake in the North Atlantic in the future (Lebehot et al., 2019). A better knowledge of DIC and TA trends (not only $f \mathrm{CO}_{2}$ ) is needed to correct and validate biogeochemical representation in 35 ESMs.

The responses of the marine biological processes to the NAO and AMO are much less studied than their physical counterpart. However, and somehow, as for $f \mathrm{CO}_{2}$, the biology link seems to also be better identified with the AMO than with the NAO. Based on the biomass variability detected from SeaWiFS over 1998-2007 in the North Atlantic and supported by biogeochemical simulations, McKinley et al. (2018) conclude that "nowhere is the NAO correlated with biomass variability". The same is true, i.e., no correlation with the NAO, when analyzing long-term in situ observations of marine species in the NA since the 1960s (Beaugrand et al., 2013; Rivero-Calle et al., 2015). However, these authors detect a significant increase in calcifying species (coccolithophores, foraminifera) associated with the warming in the NA since the mid-1990s and correlated with the AMO. This increase in calcification would impact the DIC and TA concentrations in summer and thus the $f \mathrm{CO}_{2}$ trend and carbon uptake in the NA. On the other hand, this also suggests that these phytoplanktonic groups are not yet altered by acidification, a phenomenon known as the other $\mathrm{CO}_{2}$ problem (Doney et al., 2009). Indeed, the accumulation of anthropogenic $\mathrm{CO}_{2}$ in the ocean has led to a decrease in $\mathrm{pH}$ in surface waters by 0.1 unit since the industrial revolution (IPCC, 2013 - Hart- 
mann et al., 2013). It is projected that surface pH would be reduced by 0.2 to 0.4 units by the end of the century depending on the anthropogenic emission scenario (Orr et al., 2005; Doney et al., 2014; Jiang et al., 2019). This would be associated with a dramatic reduction of the aragonite saturation horizon at high latitudes, from $2000 \mathrm{~m}$ at present up to $100 \mathrm{~m}$ by 2100 in the North Atlantic (north of $50^{\circ} \mathrm{N}$ ). Indeed, these northern surface waters (north of $50^{\circ} \mathrm{N}$ ) have initially low $\mathrm{CaCO}_{3}$ saturation because of high natural (preindustrial) DIC concentrations due to low temperatures giving high $\mathrm{CO}_{2}$ solubility. Such fast lysocline shoaling based on a simulation (Orr et al., 2005) is starting to be observed in this region (e.g., Vázquez-Rodríguez et al., 2012). Due to the potential threat to marine life, the decrease in $\mathrm{pH}$ is now recognized as a true indicator of global change, similarly to warming and sea level rise (World Meteorological Organization, 2018). The urgent need to document and understand changes in oceanic $\mathrm{pH}$ and its impact on marine life has motivated more studies in recent years. Among them, the data syntheses from Lauvset et al. (2015) and Bates et al. (2014) indicated that $\mathrm{pH}$ is decreasing in most of the surface ocean as a result of the increase in oceanic $\mathrm{CO}_{2}$. In the North Atlantic they reported a decrease in $\mathrm{pH}$ ranging between $-0.001 \mathrm{yr}^{-1}$ in the subtropical region and $-0.0026 \mathrm{yr}^{-1}$ in the Irminger Sea. These results have been confirmed at a regional scale. Based on 12 cruises conducted in summer between 1991 and 2015 in the Irminger and Iceland basins, García-Ibáñez et al. (2016) identified a pH decrease in all water masses, with the largest change in surface and intermediate waters of between -0.0016 and $-0.0018 \mathrm{yr}^{-1}$. They conclude that it is mainly due to anthropogenic $\mathrm{CO}_{2}$ and modulated by change in alkalinity. Recently Omar et al. (2019) analyzed regular surface observations during 2004-2015 in the North Sea; when selecting winter data in the North Atlantic surface waters they found significant long-term trends of $f \mathrm{CO}_{2}$ and $\mathrm{pH}$ of $+2.4 \mu \mathrm{atm} \mathrm{yr} \mathrm{r}^{-1}$ and $-0.0024 \mathrm{yr}^{-1}$, consistent with results obtained in the subpolar North Atlantic (Bates et al., 2014; Lauvset and Gruber, 2014). A driver analysis indicates that $f \mathrm{CO}_{2}$ and $\mathrm{pH}$ trends are almost entirely explained by increasing DIC due to anthropogenic $\mathrm{CO}_{2}$ uptake (Omar et al., 2019).

As anthropogenic $\mathrm{CO}_{2}$ accumulates each year in the surface and interior ocean with a direct impact on both air-sea $\mathrm{CO}_{2}$ exchange and $\mathrm{pH}$, it is important to conduct and maintain regular observations to follow the evolution of the ocean carbonate system properties and interpret how they vary from interannual to multi-decadal scales in relation with physical and biological changes. The aim of this study is to document the recent evolution of the surface $\mathrm{CO}_{2}$ system parameters in the NASPG and to evaluate the drivers for the evolution of surface $f \mathrm{CO}_{2}$ and $\mathrm{pH}$ for winter and summer. We mostly use total alkalinity (TA) and dissolved inorganic carbon (DIC) discrete observations, while other studies are based on observations of partial pressure of $\mathrm{CO}_{2}\left(p \mathrm{CO}_{2}\right)$ and TA-salinity relations (Lauvset and Gruber, 2014; Lauvset et al., 2015).

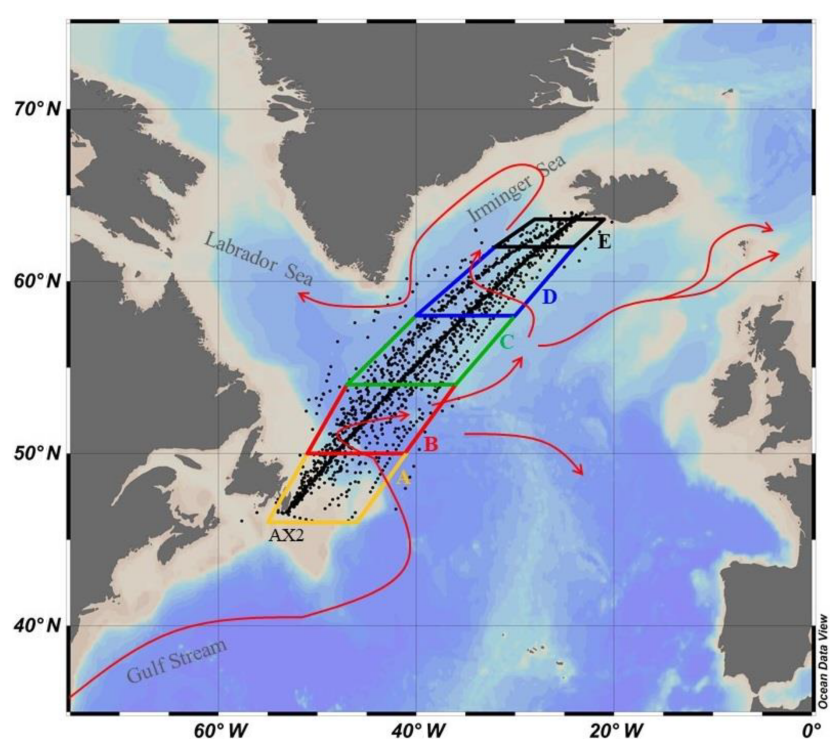

Figure 1. SURATLANT cruise tracks (in black, TA-DIC data over the period 1993-2017) with the five boxes (box A: $46-50^{\circ} \mathrm{N}$ (in yellow), box B: $50-54^{\circ} \mathrm{N}$ (in red), box C: $54-58^{\circ} \mathrm{N}$ (in green), box D: $58-62^{\circ} \mathrm{N}$ (in blue), box E: $62-64^{\circ} \mathrm{N}$ (in black)) and surface currents in the North Atlantic Subpolar Gyre (NASPG) circulation resulting from the Gulf Stream and the North Atlantic Current (in red).

The observations were collected in 1993-2017 between Iceland and Newfoundland, and this extends previous analyses based on winter SURATLANT observations in 1993-2008 to both summer and winter (Corbière et al., 2007; Metzl et al., 2010).

The NASPG as defined here extends from the east coast of Canada $\left(65^{\circ} \mathrm{W}\right)$ to the west of northern Europe $\left(5^{\circ} \mathrm{W}\right)$ mostly north of $45^{\circ} \mathrm{N}$ (Fig. 1). It consists mostly of the Labrador, Irminger and Iceland basins, and the Rockall Plateau and Trough. The NASPG is a region of mixing between subtropical, subpolar and polar surface waters. The inflow of these surface waters is dominated by three surface currents: the North Atlantic Current (NAC), also known in this sector as the North Atlantic Drift, mostly of subtropical origin; the East Greenland Current (EGC); and the Labrador Current (LC), which are the conduits that bring waters from further north and the Arctic (Fig. 1). The North Atlantic Drift delimits the NASPG in the south and transports warm $\left(8^{\circ} \mathrm{C}\right.$ to $15^{\circ} \mathrm{C}$ ) and salty (35 to 36 ) subtropical surface waters to the north. These waters are then cooled as they circulate in the NASPG due to a loss of heat to the atmosphere, while they become less salty due to excess local precipitation and freshwater inputs from the Arctic and the ice sheet. The East Greenland Current (EGC) and Labrador Current (LC) are the western branches of the NASPG and carry cold $\left(<4^{\circ} \mathrm{C}\right)$ and fresh $(<34.6)$ waters of polar origin. The study area is mostly in the central part of the NASPG between Iceland and Newfoundland. 


\section{Materials and method}

\subsection{Data collection and measurements}

This study is based on observations collected in the framework of the long-term monitoring program SURATLANT (SURveillance de l'ATLANTique) initiated in 1993. The main objective of this program is to monitor hydrological and biogeochemical properties in surface waters of the NASPG, notably sea surface salinity (SSS), to improve the understanding of the role of salinity in the variability and predictability of climate as well as the water cycle (Reverdin et al., 2018a; Holliday et al., 2020). To this end, two to four cruises per year are conducted between Reykjavík (Iceland) and Newfoundland (Canada) on board merchant ships. Seawater samples are collected every 3 to $4 \mathrm{~h}$ from a pumping system (at approximately $5 \mathrm{~m}$ deep) in order to measure salinity, as well as alkalinity (measured since 2001), DIC, silicate, nitrate and phosphate concentrations.

Underway measurements of sea surface temperature (SST) are obtained using a Sea-Bird thermosalinograph, with a precision of $\pm 0.1^{\circ} \mathrm{C}$. SSS values in this paper are from sample measurements of conductivity using a Guildline AUTOSAL salinometer since 1997 at the Marine and Freshwater Research Institute (MFRI) in Reykjavík (the associated error is estimated at \pm 0.005 ). For TA and DIC, the $500 \mathrm{~mL}$ glass bottles are rinsed three times before introducing seawater (avoiding introducing air bubbles) with an overflow in order to remove the water in contact with air during filling. The samples are then poisoned with mercuric chloride and stored in a cool, dark place. Since 2001, these samples are measured within 3 months of collection at the SNAPO-CO $\mathrm{CO}_{2}$ (Service National d'Analyse des Paramètres Océaniques du $\mathrm{CO}_{2}$ ) located at the laboratory LOCEAN in Paris. The accuracy is on the order of $\pm 3 \mu \mathrm{mol} \mathrm{kg}^{-1}$ for both DIC and TA based on Certified Reference Material (CRM) analysis and occasional intercomparisons as explained by Reverdin et al. (2018b). Samples for the analysis of nutrient concentrations are frozen just after sampling. Spring and summer samples are filtered before analysis. The measurements are carried out by the MFRI team in Reykjavík according to the standard colorimetric method described by Ólafsson et al. (2010) with an accuracy of $\pm 0.2 \mu \mathrm{mol} \mathrm{L}^{-1}$ for nitrate and silicate and $\pm 0.03 \mu \mathrm{mol} \mathrm{L}^{-1}$ for phosphate. Details of the sampling and analyses for all properties are provided in Reverdin et al. (2018b). The SURATLANT dataset is freely available and is accessible at http://www.seanoe.org/data/ 00434/54517/ (last access: 11 March 2019). In the SURATLANT data file, each sample and data are associated with a quality flag (based on WOCE flag criteria, i.e., the same as used in GLODAP database; Olsen et al., 2016). In this study we use only data qualified with flag 2 (acceptable data).

\subsection{Calculations of the carbonate system parameters and contributions}

Carbonate system parameters such as $\mathrm{pH}$, the fugacity of $\mathrm{CO}_{2}\left(f \mathrm{CO}_{2}\right)$ and the saturation states for the calcium carbonate minerals calcite $\left(\Omega_{\mathrm{Ca}}\right)$ and aragonite $\left(\Omega_{\mathrm{Ar}}\right)$ are calculated using SST, SSS, TA, DIC, silicate and phosphate data described by Reverdin et al. (2018b). For the last two, we used monthly climatological values derived from the SURATLANT data over the period 1993-2017 because nutrient interannual variability does not have a significant impact on the carbonate system parameter calculations (and because nutrients were missing for some cruises). The calculation program used is $\mathrm{CO}_{2} \mathrm{SYS}$ originally developed by Lewis et al. (1998) available in MATLAB (van Heuven et al., 2011) that now includes error propagation (Orr et al., 2018). The constants of the thermodynamic equilibrium of $\mathrm{CO}_{2}$ in seawater used are $K_{1}$ (for the dissociation of carbonic acid) and $K_{2}$ (for the bicarbonate ion) defined by Mehrbach et al. (1973), refitted by Dickson and Millero (1987). The total boron value is calculated according to Uppström (1974), and the $\mathrm{KHSO}_{4}$ dissociation constant is from Dickson (1990). The adopted $\mathrm{pH}$ scale is total scale.

When TA was not measured (notably before 2001), it was calculated from salinity data. The correlation between sea surface alkalinity and salinity in the open ocean can be described with an empirical linear relationship (Millero et al., 1998; Friis et al., 2003). For the NASPG, the original TA-SSS relation used to analyze $f \mathrm{CO}_{2}$ variability and trend in 1993-2007 (e.g., Corbière et al., 2007; Metzl et al., 2010; McKinley et al., 2011) was revisited by Reverdin et al. (2018b) based on SURATLANT data over the period 2001-2016 (Eq. 1). This equation was obtained for samples collected north of $50^{\circ} \mathrm{N}$ with $\mathrm{SSS}>34$.

$\mathrm{TA}=45.5337 \times \mathrm{SSS}+713.58$

To evaluate the air-sea $\mathrm{CO}_{2}$ difference (delta- $f \mathrm{CO}_{2}$ ) for each sample, we used atmospheric $f \mathrm{CO}_{2}$ values for the period 1993-2017 calculated from the molar fraction $\left(x \mathrm{CO}_{2}\right)$ data at Mace Head provided by the Cooperative Global Atmospheric Data Integration Project (Dlugokencky et al., 2019). The $x \mathrm{CO}_{2}$ data are available at $\mathrm{http} / / / \mathrm{www} . e s r l$. noaa.gov/gmd/dv/iadv/ (last access: 6 March 2019). $x \mathrm{CO}_{2}$ data were converted to $f \mathrm{CO}_{2}$ at $100 \%$ humidity following Weiss and Price (1980), with standard atmospheric pressure (i.e., $1013.25 \mathrm{hPa}$ ).

The trends in sea surface $\mathrm{pH}, f \mathrm{CO}_{2}$ and $\Omega$ are driven by changes in SST, SSS, TA and DIC (Keeling et al., 2004; Fröb et al., 2019). For DIC, this includes anthropogenic $\mathrm{CO}_{2}$ concentration (Cant) and the DIC natural component (DICnat $=$ DIC-Cant). The contribution of each term for a specific period and season is evaluated by allowing a change in only one parameter according to their observed trend, while setting the other parameters to their climatological seasonal values (Eq. 2). The uncertainty on the contributions was eval- 
uated by performing 1000 random perturbations within the range of the standard deviation of the observed trends in SST, SSS, TA and DIC. The same method was applied when separating the effect of DIC-nat and anthropogenic $\mathrm{CO}_{2}$ (Cant).

$$
\begin{aligned}
& \frac{\mathrm{d} X}{\mathrm{~d} t}=\frac{\partial X}{\partial \mathrm{SST}} \frac{\mathrm{dSST}}{\mathrm{d} t}+\frac{\partial X}{\partial \mathrm{SSS}} \frac{\mathrm{dSSS}}{\mathrm{d} t}+\frac{\partial X}{\partial \mathrm{DIC}} \\
& \left(\overline{\frac{\mathrm{SDIC}}{\mathrm{SSS}_{0}}} \frac{\mathrm{dSSS}}{\mathrm{d} t}+\frac{\overline{\mathrm{SSS}}}{\mathrm{SSS}_{0}} \frac{\mathrm{dsDIC}}{\mathrm{d} t}\right)+\frac{\partial X}{\partial \mathrm{TA}} \\
& \left(\overline{\frac{\mathrm{sTA}}{\mathrm{SSS}_{0}}} \frac{\mathrm{dSSS}}{\mathrm{d} t}+\frac{\overline{\mathrm{SSS}}}{\mathrm{SSS}_{0}} \frac{\mathrm{dsTA}}{\mathrm{d} t}\right)
\end{aligned}
$$

Here, $X$ corresponds to $\mathrm{pH}, f \mathrm{CO}_{2}$ and $\Omega$. $\mathrm{SSS}_{0}$ is the reference salinity, which is set to 35 (Normal Standard Seawater; Millero et al., 2008) and very close to the mean salinity observed in the NASPG (SSS $=34.84)$. sDIC and sTA were computed by normalizing DIC and TA to a salinity of 35 and assuming a nonzero freshwater end-member DIC and TA concentration (Friis et al., 2003; Reverdin et al., 2018b). The trends $(\mathrm{d} X / \mathrm{d} t)$ were estimated for each season, each box and each period, and $\overline{\text { SST }}, \overline{\text { SSSTA }}$ and $\overline{\text { DIC }}$ correspond to their climatological values calculated over the same period.

The uncertainties of measured parameters (SST, SSS, DIC and TA; Fig. 4a-f) used in random calculations were based on the standard deviation associated with the averaging of the data in each box and month. For the calculated parameters ( $\mathrm{pH}, f \mathrm{CO}_{2}, \Omega_{\mathrm{Ar}}$; Fig. $4 \mathrm{~d}-\mathrm{j}$ ), the uncertainties consider the errors associated with each measurement of the calculation parameters (Orr et al., 2018). The uncertainty on the trends is linked to the discrete sampling of spatiotemporal variability within the season that we wish to analyze. The uncertainty on the trends is linked either to the discrete sampling of a spatial-temporal variability within the season analyzed or to the interannual variability (real or linked to insufficient sampling). If the uncertainty associated with the annual averages is low, then the trend uncertainty will be low and will correspond to the first part. On the other hand, in the case where the interannual (real) variability is high, the uncertainty will correspond to the second part, which will decrease the trend significance.

\subsection{Data selection: regions and seasons}

The sampled region was separated into five $4^{\circ}$ latitude boxes, from 46 to $64^{\circ} \mathrm{N}$ (Fig. 1) according to Reverdin et al. $\left(2018 \mathrm{~b}\right.$ ). The southern box (box A: $46-50^{\circ} \mathrm{N}$ ) covers the shelf and continental margin of North America and is excluded in the present long-term trend analysis because of insufficient sampling and large interannual variations due to freshwater inputs from continental runoff. Box B $\left(50-54^{\circ} \mathrm{N}\right)$ incorporates only samples where SSS is between 34 and 35 (to avoid including continental shelf or NAC waters). Thus, whereas over 470 samples with DIC data are found in box B for 1993-2017, only 399 data in the salinity range $34-35$ are considered (we excluded 38 data for $S<34$ and 33 data for $S>35)$. For boxes C $\left(54-58^{\circ} \mathrm{N}\right), \mathrm{D}\left(58-62^{\circ} \mathrm{N}\right)$ and $\mathrm{E}(62-$ $64^{\circ} \mathrm{N}$ ), we used all available data.

The trend analysis and contribution calculations (Eq. 2) were first performed for each box but results of trends and drivers for boxes $\mathrm{C}, \mathrm{D}$ and $\mathrm{E}$ were found to be quasi-identical. Therefore, we present and discuss the results by combining the data collected north of $54^{\circ} \mathrm{N}$ (i.e., boxes $\mathrm{C}, \mathrm{D}$ and $\mathrm{E}$ ). The trends in box B are evaluated separately because properties and their trends (SST, SSS, DIC, TA) differ significantly from the other three boxes. We separate seasons, and the trends for winter (January to March) and summer (June to August) are analyzed separately as they correspond to seasonal extrema of surface carbonate properties (described below in Sect. 3.1) and these seasons were more regularly sampled along the SURATLANT line (Table 1). Finally, we choose February and July as a reference for winter and summer, respectively. When February or July data were missing for a specific year, the data collected in January or March (for winter) and in June or August (for summer) were used after correcting the observed seasonal anomalies from the climatological cycles described in Sect. 3.1. We tested this reconstruction for February and July data using SST and SSS data based on the binned products from Reverdin et al. (2018a) and averaging the bins in the same boxes (B and CDE) used for discrete sampling (Fig. S1 and Table S1 in the Supplement). As expected, the differences for SST and SSS are most pronounced for summer and box B (Fig. S1a, c) due to higher variability observed during this season, both in time and at the small scale. For winter the reconstruction based on discrete sampling appears more robust when compared to the binned products, especially for box CDE (Fig. S1b, c). To interpret our results, we thus are more confident with the trends based on winter data than summer and for box CDE. No attempt to reconstruct data was made when the SURATLANT line was not sampled for at least 3 months (e.g., winter 2016 and 2017 not included in this analysis and trends limited to 1993-2015 for this season).

\section{Results}

\subsection{Seasonal cycle}

As mentioned above, the SURATLANT sampling is not available each year for the reference months of February and July selected for the summer and winter trend analysis (Table 1). When no data are available in February or July, we adjust the representative winter and summer data based on the deviations from the seasonal cycle observed in January or March (for winter) and June or August (for summer) according to Eq. (3).

$\mathrm{SST}_{\text {month(A) }}^{\text {year }}=\mathrm{SST}_{\text {month(A) }}^{\text {clim }}+\left(\mathrm{SST}_{\text {month(B) }}^{\text {year }}-\mathrm{SST}_{\text {month(B) }}^{\text {clim }}\right)$ 
Table 1. SURATLANT sampling since 1993 for each box in Fig. 1.

\begin{tabular}{|c|c|c|c|c|c|c|c|c|c|c|c|c|}
\hline & Jan & $\mathrm{Feb}$ & Mar & Apr & May & Jun & Jul & Aug & Sep & Oct & Nov & Dec \\
\hline 1993 & & & & & & & $\begin{array}{l}\text { A, B, } \\
\text { C, D, E }\end{array}$ & & & & & \\
\hline 1994 & $\begin{array}{l}\mathrm{A}, \mathrm{B}, \\
\mathrm{C}, \mathrm{D}, \mathrm{E}\end{array}$ & & & $\begin{array}{l}\mathrm{A}, \mathrm{B}, \\
\mathrm{C}, \mathrm{D}, \mathrm{E}\end{array}$ & & $\begin{array}{l}\mathrm{A}, \mathrm{B}, \\
\mathrm{C}, \mathrm{D}, \mathrm{E}\end{array}$ & & & $\begin{array}{l}\text { A, B, } \\
\text { C, D, E }\end{array}$ & & & \\
\hline 1995 & $\begin{array}{l}\mathrm{A}, \mathrm{B}, \\
\mathrm{C}, \mathrm{D}, \mathrm{E}\end{array}$ & & & & $\begin{array}{l}\mathrm{A}, \mathrm{B}, \\
\mathrm{C}, \mathrm{D}, \mathrm{E}\end{array}$ & & $\begin{array}{l}\mathrm{A}, \mathrm{B}, \\
\mathrm{C}, \mathrm{D}, \mathrm{E}\end{array}$ & & & & & $\mathrm{A}, \mathrm{B}, \mathrm{C}$ \\
\hline 1996 & C, D, E & & $\begin{array}{l}\mathrm{A}, \mathrm{B}, \\
\mathrm{C}, \mathrm{D}, \mathrm{E}\end{array}$ & & & & $\begin{array}{l}\mathrm{A}, \mathrm{B}, \\
\mathrm{C}, \mathrm{D}, \mathrm{E}\end{array}$ & & & & & \\
\hline 1997 & & $\begin{array}{l}\text { A, B, } \\
\text { C, D, E }\end{array}$ & & & & & & & & & & \\
\hline 2001 & & & & & & $\begin{array}{l}\text { A, B, } \\
\text { C, D, E }\end{array}$ & & $\begin{array}{l}\text { A, B, } \\
\text { C, D, E }\end{array}$ & & & & $\begin{array}{l}\text { A, B, } \\
\text { C, D, E }\end{array}$ \\
\hline 2002 & & $\begin{array}{l}\mathrm{A}, \mathrm{B}, \\
\mathrm{C}, \mathrm{D}, \mathrm{E}\end{array}$ & & & $\begin{array}{l}\mathrm{A}, \mathrm{B}, \\
\mathrm{C}, \mathrm{D}, \mathrm{E}\end{array}$ & & & & $\begin{array}{l}\mathrm{A}, \mathrm{B}, \\
\mathrm{C}, \mathrm{D}, \mathrm{E}\end{array}$ & & & $\begin{array}{l}\mathrm{A}, \mathrm{B}, \\
\mathrm{C}, \mathrm{D}\end{array}$ \\
\hline 2003 & & & & $\begin{array}{l}\mathrm{A}, \mathrm{B}, \\
\mathrm{C}, \mathrm{D}, \mathrm{E}\end{array}$ & & & $\begin{array}{l}\mathrm{A}, \mathrm{B}, \\
\mathrm{C}, \mathrm{D}, \mathrm{E}\end{array}$ & & & $\begin{array}{l}\text { B, C, } \\
\text { D, E }\end{array}$ & & \\
\hline 2004 & $\begin{array}{l}\mathrm{B}, \mathrm{C}, \\
\mathrm{D}, \mathrm{E}\end{array}$ & & & & $\begin{array}{l}\text { B, C, } \\
\text { D, E }\end{array}$ & & $\begin{array}{l}\text { A, B, } \\
\text { C, D, E }\end{array}$ & & & & $\begin{array}{l}\text { B, C, } \\
\text { D, E }\end{array}$ & \\
\hline 2005 & & & & & $\begin{array}{l}\mathrm{A}, \mathrm{B}, \\
\mathrm{C}, \mathrm{D}, \mathrm{E}\end{array}$ & A & $\begin{array}{l}\text { A, B, } \\
\text { C, D, E }\end{array}$ & & & & $\begin{array}{l}\text { B, C, } \\
\text { D, E }\end{array}$ & \\
\hline 2006 & & $\begin{array}{l}\mathrm{B}, \mathrm{C} \\
\mathrm{D}, \mathrm{E}\end{array}$ & & & $\begin{array}{l}\mathrm{A}, \mathrm{B}, \\
\mathrm{C}, \mathrm{D}, \mathrm{E}\end{array}$ & & $\mathrm{A}, \mathrm{B}, \mathrm{C}$ & & & & $\begin{array}{l}\mathrm{A}, \mathrm{B}, \\
\mathrm{C}, \mathrm{D}, \mathrm{E}\end{array}$ & \\
\hline 2007 & & $\begin{array}{l}\text { B, C, } \\
\text { D, E }\end{array}$ & & & & & & $\begin{array}{l}\text { A, B, } \\
\text { C, D, E }\end{array}$ & & $\begin{array}{l}\text { A, B, } \\
\text { C, D, E }\end{array}$ & & \\
\hline 2008 & & & $\begin{array}{l}\mathrm{A}, \mathrm{B}, \\
\mathrm{C}, \mathrm{D}, \mathrm{E}\end{array}$ & & $\begin{array}{l}\mathrm{B}, \mathrm{C}, \\
\mathrm{D}, \mathrm{E}\end{array}$ & & B & $\mathrm{C}, \mathrm{D}, \mathrm{E}$ & & & $\begin{array}{l}\mathrm{A}, \mathrm{B}, \\
\mathrm{C}, \mathrm{D}, \mathrm{E}\end{array}$ & \\
\hline 2009 & & $\begin{array}{l}\mathrm{A}, \mathrm{B}, \\
\mathrm{C}, \mathrm{D}, \mathrm{E}\end{array}$ & & & & $\begin{array}{l}\mathrm{A}, \mathrm{B}, \\
\mathrm{C}, \mathrm{D}, \mathrm{E}\end{array}$ & & & $\begin{array}{l}\text { B, C, } \\
\text { D, E }\end{array}$ & & & $\begin{array}{l}\text { A, B, } \\
\text { C, D, E }\end{array}$ \\
\hline 2010 & & & $\begin{array}{l}\text { B, C, } \\
\text { D, E }\end{array}$ & & & $\begin{array}{l}\mathrm{A}, \mathrm{B}, \\
\mathrm{C}, \mathrm{D}, \mathrm{E}\end{array}$ & & $\begin{array}{l}\mathrm{A}, \mathrm{B}, \\
\mathrm{C}, \mathrm{D}, \mathrm{E}\end{array}$ & & & & $\begin{array}{l}\mathrm{A}, \mathrm{B}, \\
\mathrm{C}, \mathrm{D}, \mathrm{E}\end{array}$ \\
\hline 2011 & & & $\begin{array}{l}\text { B, C, } \\
\text { D, E }\end{array}$ & & & & & & & & & $\begin{array}{l}\text { B, C, } \\
\text { D, E }\end{array}$ \\
\hline 2012 & & & $\begin{array}{l}\mathrm{A}, \mathrm{B}, \\
\mathrm{C}, \mathrm{D}, \mathrm{E}\end{array}$ & & & E & $\begin{array}{l}\mathrm{A}, \mathrm{B}, \\
\mathrm{C}, \mathrm{D}, \mathrm{E}\end{array}$ & & $\begin{array}{l}\text { A, B, } \\
\text { C, D, E }\end{array}$ & & & $\begin{array}{l}\text { A, B, } \\
\text { C, D }\end{array}$ \\
\hline 2013 & & & $\begin{array}{l}\mathrm{B}, \mathrm{C} \\
\mathrm{D}, \mathrm{E}\end{array}$ & & & & $\begin{array}{l}\mathrm{A}, \mathrm{B}, \\
\mathrm{C}, \mathrm{D}, \mathrm{E}\end{array}$ & & $\begin{array}{l}\text { B, C, } \\
\text { D, E }\end{array}$ & A & & \\
\hline 2014 & $\begin{array}{l}\text { A, B, } \\
\text { C, D, E }\end{array}$ & & & $\begin{array}{l}\mathrm{A}, \mathrm{B}, \\
\mathrm{C}, \mathrm{D}, \mathrm{E}\end{array}$ & & & $\begin{array}{l}\text { A, B, } \\
\text { C, D, E }\end{array}$ & & & $\begin{array}{l}\text { A, B, } \\
\text { C, D, E }\end{array}$ & & \\
\hline 2015 & $\begin{array}{l}\mathrm{A}, \mathrm{B}, \\
\mathrm{C}, \mathrm{D}, \mathrm{E}\end{array}$ & & & & & $\begin{array}{l}\mathrm{A}, \mathrm{B}, \\
\mathrm{C}, \mathrm{D}, \mathrm{E}\end{array}$ & & & $\begin{array}{l}\text { A, B, } \\
\text { C, D, E }\end{array}$ & & & $\begin{array}{l}\mathrm{A}, \mathrm{B}, \\
\mathrm{C}, \mathrm{D}, \mathrm{E}\end{array}$ \\
\hline 2016 & & & & $\begin{array}{l}\mathrm{A}, \mathrm{B}, \\
\mathrm{C}, \mathrm{D}, \mathrm{E}\end{array}$ & & & $\begin{array}{l}\mathrm{A}, \mathrm{B}, \\
\mathrm{C}, \mathrm{D}, \mathrm{E}\end{array}$ & & & $\begin{array}{l}\text { B, C, } \\
\text { D, E }\end{array}$ & & \\
\hline 2017 & & & & & & & $\begin{array}{l}\text { B, C, } \\
\text { D, E }\end{array}$ & C, D & & & & \\
\hline
\end{tabular}


Here, month(A) corresponds to February or July, month(B) to January or March (for winter) and June or August (for summer), and clim to climatology.

The mean seasonal cycles constructed from data collected over the period 1993-2017 (only 2001-2017 for TA) are portrayed in Fig. 2. For nutrients (not shown here) the seasonal cycle was described by Reverdin et al. (2018b). The seasonal cycles deduced here from the SURATLANT data represent classical variability observed in the North Atlantic north of $50^{\circ} \mathrm{N}$ and are coherent with other climatology of the oceanic carbonate system constructed from different data and methods (Lee et al., 2006; Takahashi et al., 2009, 2014; Becker et al., 2018). Except for salinity and TA, all properties show a marked seasonality in all regions with maxima and minima identified at the same period for boxes B, C, D and E. For the northern box E (62-64 ${ }^{\circ}$ N, black lines in Fig. 2), we note some short time variability during summer for salinity and TA (minimum in July) that impacts the $f \mathrm{CO}_{2}, \mathrm{pH}$ and $\Omega$ cycles in this region.

The mean monthly DIC concentration (Fig. 2d) is at a maximum in winter due to deep vertical mixing, presents a steep decline from April to May when phytoplankton blooms start to occur and shows a minimum at the end of summer. The mean DIC concentrations are very similar each month north of $54^{\circ} \mathrm{N}$ (boxes $\mathrm{C}, \mathrm{D}, \mathrm{E}$ ) and significantly lower in the southern region (box B, red line in Fig. 2) because salinity is also lower and the temperature is higher from June to November in the south. The seasonal DIC amplitude of around $70-80 \mu \mathrm{mol} \mathrm{kg}^{-1}$ in the north is slightly more pronounced in the south at around $90 \mu \mathrm{mol} \mathrm{kg}^{-1}$. Given the variability from year to year, the mean seasonal cycles of $f \mathrm{CO}_{2}$, $\mathrm{pH}$ and $\Omega_{\mathrm{Ar}}$ (Fig. 2e, f, g) show fairly similar variations in all boxes. As the alkalinity seasonality is low, the seasonal changes in $f \mathrm{CO}_{2}$ and $\mathrm{pH}$ are anticorrelated and the seasonal variability of $\Omega$ is relatively similar to that of $\mathrm{pH}$.

Although the temperature is +3 to $+6^{\circ} \mathrm{C}$ warmer in summer compared to winter (Fig. 2a), the seasonal $f \mathrm{CO}_{2}$ variability is mainly driven by DIC, i.e., the biological production in spring-summer dominates the effect of warming and deep mixing in winter dominates the cooling effect. The seasonal amplitude of $f \mathrm{CO}_{2}$ that varies between 50 and $70 \mu \mathrm{atm}$ (Fig. 4e) is much larger than in the atmosphere (around $14 \mu \mathrm{atm}$ at these latitudes). Consequently, for climatology, the NASPG is near equilibrium in winter and a strong $\mathrm{CO}_{2}$ sink in summer. How and why this $\mathrm{CO}_{2}$ sink changes over 1993-2017 will be investigated in the next sections.

\subsection{Long-term trend and anthropogenic $\mathrm{CO}_{2}$}

When describing the SURATLANT dataset for 1993-2017, Reverdin et al. (2018b) evaluated the long-term trend of properties over a broad region $\left(50-63^{\circ} \mathrm{N}\right)$. Using data over 24 years (and all seasons) they estimate an increase in DIC of $+0.77( \pm 0.11) \mu \mathrm{mol} \mathrm{kg} \mathrm{kg}^{-1} \mathrm{yr}^{-1}$, a $f \mathrm{CO}_{2}$ trend of $+1.95( \pm 0.12) \mu \mathrm{atm} \mathrm{yr}^{-1}$ and a $\mathrm{pH}$ decrease of -0.0021

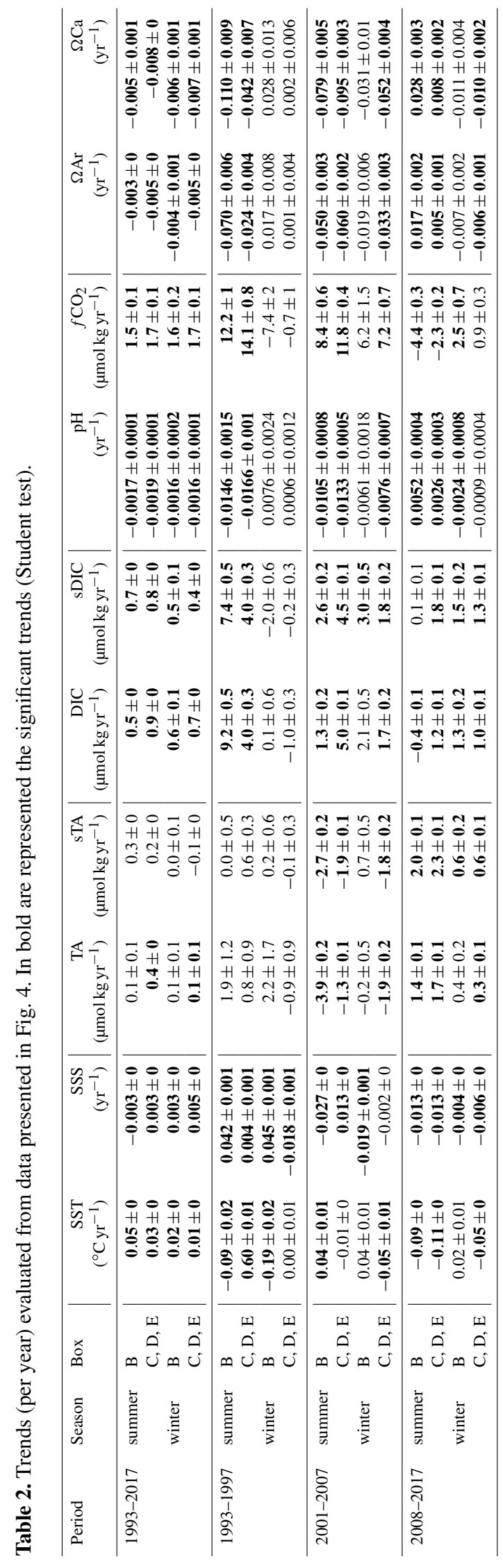

Biogeosciences, 17, 2553-2577, 2020 

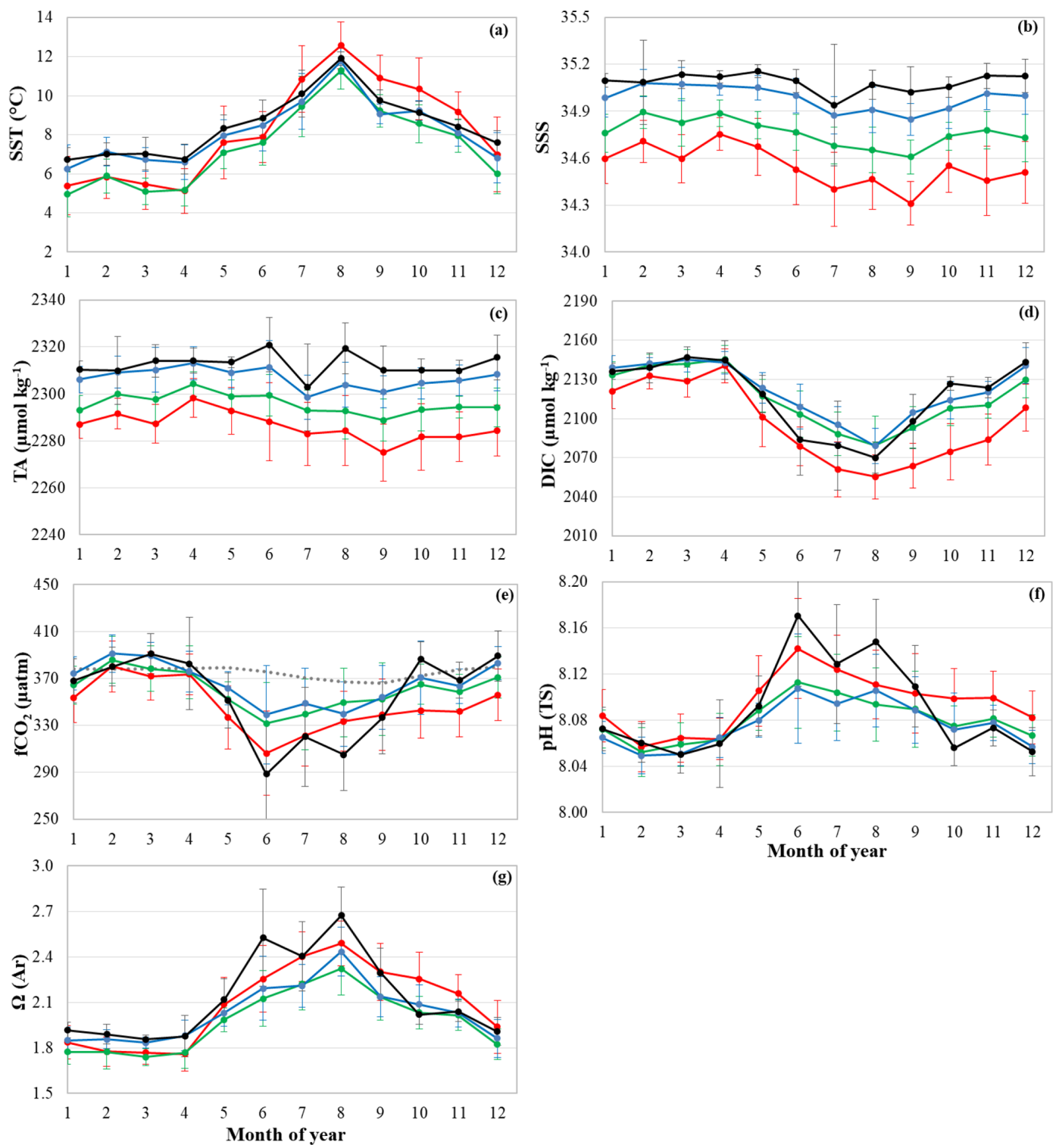

(g)

Figure 2. Mean seasonal cycle of (a) SST, (b) SSS, (c) TA, (d) DIC, (e) $f \mathrm{CO}_{2}$, (f) $\mathrm{pH}$ and (g) $\Omega$ (Ar) over the period 1993-2017 in boxes B, $\mathrm{C}, \mathrm{D}$ and $\mathrm{E}$ identified with corresponding colors in Fig. 1. Mean seasonal cycle of atmospheric $f \mathrm{CO}_{2}$ from Mace Head station is represented by grey dots in (e). Errors bars result from both interannual and spatial variability within a box.

$( \pm 0.0001) \mathrm{yr}^{-1}$. Here we re-evaluate these trends in each box (B, CDE merged) and only for summer (July) or winter (February) using observations and reconstructed data as described in Sect. 2.3. The trends for 1993-2017 in each box and season are listed in Table 2 (first lines). The DIC increasing rate ranges between +0.5 and $+0.9 \mu \mathrm{mol} \mathrm{kg}^{-1} \mathrm{yr}^{-1}$ depending on the season and region. For $f \mathrm{CO}_{2}$ we evaluate trends ranging between +1.5 and $+1.7 \mu$ utm yr$^{-1}$ and for $\mathrm{pH}$ between -0.0016 and $-0.0019 \mathrm{yr}^{-1}$. Not surprisingly, because the same original data are used, the summer and winter trends for each box (B, CDE) are consistent with preliminary results from Reverdin et al. (2018b). From 1993 to 2017, we also observed a warming, most pronounced in summer (up to $+0.05^{\circ} \mathrm{Cyr}^{-1}$, Table 2), but the $f \mathrm{CO}_{2}$ increase and $\mathrm{pH}$ decrease are mainly explained by DIC increase. The long-term $f \mathrm{CO}_{2}$ and $\mathrm{pH}$ changes are thus mainly attributed to anthropogenic $\mathrm{CO}_{2}$ uptake. This is also supported by a decrease in $\delta^{13} \mathrm{C}_{\text {DIC }}$ (Suess effect) along the SURATLANT track but for a shorter period, 2005-2017 (Reverdin et al., 2018b), a signal observed at depth in the Irminger Basin between 1981 and 2006 and linked to anthropogenic $\mathrm{CO}_{2}$ (Racapé et al., 2013).

To gain insight into the DIC trends and separate natural versus anthropogenic contributions to the $f \mathrm{CO}_{2}$ and $\mathrm{pH}$ trends, we evaluate the anthropogenic DIC (hereafter denoted C-ant) in the NASPG region. Here we use the TrOCA 
method (Tracer Combining Oxygen, Inorganic Carbon and Total Alkalinity; Touratier et al., 2007) applied to data available in the GLODAPv2 database (Key et al., 2015; Olsen et al., 2016). In the NASPG, repeated observations since 1997 were mostly conducted during summer (13 cruises in JuneSeptember). Because indirect methods such as TrOCA are not suitable to evaluate $\mathrm{C}$-ant concentrations in surface waters (due to biological activity and gas exchange), we calculate C-ant in the layer 150-200 m only. For the period 19972010 , we estimate a C-ant trend of $+0.6 \mu \mathrm{mol} \mathrm{kg}^{-1} \mathrm{yr}^{-1}$ in the NASPG. The anthropogenic signal would explain $65 \%$ of the DIC trend of $+0.9 \mu \mathrm{mol} \mathrm{kg}^{-1} \mathrm{yr}^{-1}$ observed in GLODAPv2 subsurface data for the same period in the region 54$64^{\circ} \mathrm{N}, 40-20^{\circ} \mathrm{W}$. Note that we obtain similar results when selecting different periods $\left(\mathrm{C}\right.$-ant $=+0.53 \mu \mathrm{mol} \mathrm{kg}^{-1} \mathrm{yr}^{-1}$ for $1997-2007$ whereas it is $+0.58 \mu \mathrm{mol} \mathrm{kg}^{-1} \mathrm{yr}^{-1}$ when restricted to 2001-2007).

Recently, a new data-based method, eMLR( $\left(C^{*}\right)$, developed by Clement and Gruber, (2018) was used to evaluate the accumulation of C-ant from 1994 to 2007 in the global ocean (Gruber et al., 2019a). To compare with our estimates based on TrOCA, we explore the $\mathrm{C}$-ant concentrations from $\operatorname{eMLR}\left(\mathrm{C}^{*}\right)$ in the NASPG (data extracted from Gruber et al., 2019b). Along the SURATLANT line, the accumulated C-ant between 1994 and 2007 is $+8.5( \pm 1.7) \mu \mathrm{mol} \mathrm{kg}-1$ in the layer $150-200 \mathrm{~m}$. This would correspond to a $\mathrm{C}$-ant trend of $+0.65 \mu \mathrm{mol} \mathrm{kg} \mathrm{yr}^{-1}$ close to our C-ant estimate based on GLODAPv2 and the TrOCA method in the same layer. This is not surprising as Gruber et al. (2019a, b) used GLODAPv2 data as well. In the surface layer, the $\operatorname{eMLR}\left(\mathrm{C}^{*}\right)$ method leads to a $\mathrm{C}$-ant accumulation in the layer $0-50 \mathrm{~m}$ along the SURATLANT line $\left(55-64^{\circ} \mathrm{N}\right)$ of +10.1 $( \pm 0.8) \mu \mathrm{mol} \mathrm{kg} \mathrm{gr}^{-1}$ between 1994 and 2007, i.e., about $+0.8 \mu \mathrm{mol} \mathrm{kg}-1 \mathrm{yr}^{-1}$. Again, this is in the range of the longterm (1993-2017) DIC surface trends that we report (Table 2) between +0.7 and $+0.9 \mu \mathrm{mol} \mathrm{kg}^{-1} \mathrm{yr}^{-1}$ in boxes $\mathrm{CDE}$ (depending on the season). Interestingly, in the region $55-64^{\circ} \mathrm{N}$ winter DIC from SURATLANT averaged 2134.1 $( \pm 2.8) \mu \mathrm{mol} \mathrm{kg}^{-1}$ in 1994 and $2145.1( \pm 2.1) \mu \mathrm{mol} \mathrm{kg}{ }^{-1}$ in 2007 , i.e., an increase of $+11 \mu \mathrm{mol} \mathrm{kg}{ }^{-1}$ almost equal to the $\mathrm{C}$-ant accumulation deduced from $\operatorname{eMLR}\left(\mathrm{C}^{*}\right)$ over the same period. These independent estimates confirm that in the NASPG the observed long-term DIC trend and derived trends for $f \mathrm{CO}_{2}$ and $\mathrm{pH}$ in surface waters (Table 2, 19932017) are mostly linked with anthropogenic $\mathrm{CO}_{2}$ uptake. The same conclusion was drawn for the subpolar mode waters found in subsurface layers in the NASPG (VázquezRodríguez et al., 2012; García-Ibáñez et al., 2016; Fröb et al., 2018). For example, based on data collected in 19812008, Vázquez-Rodríguez et al. (2012) estimated that $75 \%$ of the observed $\mathrm{pH}$ decrease $\left(-0.0019 \mathrm{yr}^{-1}\right)$ in the subarctic intermediate waters (SAIW) in the Irminger Basin is due to anthropogenic DIC. García-Ibáñez et al. (2016), incorporating four additional cruises (2010-2015), estimated a $\mathrm{pH}$ decrease of around $-0.0018 \mathrm{yr}^{-1}$ over $1991-2015$ in the subpolar mode waters (SPMW) found at around 200$300 \mathrm{~m}$ in the Irminger Basin. They also conclude that in the SPMW the $\mathrm{pH}$ decrease is dominated by DIC increase $\left(+0.82 \mu \mathrm{mol} \mathrm{kg} \mathrm{gr}^{-1}\right)$ through anthropogenic $\mathrm{CO}_{2}(\mathrm{C}$-ant trend of $+0.9 \mu \mathrm{mol} \mathrm{kg}^{-1} \mathrm{yr}^{-1}$ ) but this is modulated by a $\mathrm{pH}$ increase over time due to an increase in alkalinity (about $+0.11 \mu \mathrm{mol} \mathrm{kg}{ }^{-1} \mathrm{yr}^{-1}$ ). From the SURATLANT time series (1993-2017) we also observe a small increase in TA during winter $\left(+0.1 \mu \mathrm{mol} \mathrm{kg}^{-1} \mathrm{yr}^{-1}\right.$, Table 2$)$ coherent with the TA signal observed in the SPMW layer from data collected in summer (García-Ibáñez et al., 2016). The TA increase in the SPMW layer in the Irminger Basin is directly linked with salinity increase (García-Ibáñez et al., 2016) attributed to advection of higher salinity of subtropical origin and also associated with the contraction of the subpolar gyre since the mid-1990s (Häkkinen and Rhines, 2004). However, we observed a much stronger TA increase in surface water during summer, up to $+0.4 \mu \mathrm{mol} \mathrm{kg}^{-1} \mathrm{yr}^{-1}$ in the northern region (Table 2, box CDE). Such a TA increase would lead to a $\mathrm{pH}$ change of around $+0.0009 \mathrm{yr}^{-1}$, counteracting the impact of DIC increase. In addition, when TA is normalized in salinity, we evaluate summer sTA trends of $+0.2 \mu \mathrm{mol} \mathrm{kg} \mathrm{gr}^{-1}$ in the north and $+0.3 \mu \mathrm{mol} \mathrm{kg}{ }^{-1} \mathrm{yr}^{-1}$ in the south (Table 2), suggesting that the TA changes are not solely linked to salinity and advective process.

At high latitudes in the open ocean, such a long-term positive TA trend was only observed (to our knowledge) in the Pacific Western Subarctic Gyre (Wakita et al., 2013, 2017). There, in the winter mixed layer, Wakita et al. (2017) estimate positive TA and sTA trends of +0.4 and $+0.34 \mu \mathrm{mol} \mathrm{kg} \mathrm{yr}^{-1}$ over $1999-2015$. This leads to a long-term $\mathrm{pH}$ decrease in this region $\left(-0.0008 \mathrm{yr}^{-1}\right)$ much slower than observed in other open-ocean times series stations (Bates et al., 2014) and in the NASPG for 1993-2017 (Table 2). The TA increase also leads to slow $f \mathrm{CO}_{2}$ increase $+0.9 \mu^{2}$ atm yr$^{-1}$ (Wakita et al., 2017). Wakita et al. (2017) suggested the TA increase might be due to weakened calcification (but this process was not quantified). Therefore, in addition to advection or convective processes, biological process such as calcification cannot be ruled out to explain TA and sTA long-term positive trends observed during summer in the NASPG (Table 2). At the high latitudes of the North Atlantic, blooms of coccolithophorid (Emiliania huxleyi) are well captured from space (Brown and Yoder, 1994), and there is indication that these blooms were more pronounced in the 1990s compared to the last 2 decades, 2000-2017 (Loveday and Smyth, 2018). Thus, in addition to DIC and anthropogenic $\mathrm{CO}_{2}$, a better knowledge of temporal TA dynamics is relevant for an understanding of $f \mathrm{CO}_{2}$ and $\mathrm{pH}$ changes. It is worth noting that ocean biogeochemical models (OBGMs) used to quantify the carbon cycle at a large scale are not able to fully capture TA variability when calcifying phytoplankton is not explicitly included (Ullman et al., 2009, who used 1993-2005 SURATLANT data for model comparison). When multiple phytoplankton functional groups including 
coccolithophores are explicitly parameterized in ecosystem carbon models, the seasonal cycle of both DIC and TA are better represented in the NASPG (Signorini et al., 2012). The same is likely true to interpret interannual to decadal TA variability and explain the drivers of observed $f \mathrm{CO}_{2}$ and $\mathrm{pH}$ trends along the SURATLANT line.

Because interannual variability is more pronounced in summer than in winter because of the added influence of biological activity, most studies focused on winter to analyze and interpret the decadal trends of the carbonate system in surface waters (Olafsson et al., 2009; Metzl et al., 2010; Fröb et al., 2019; Omar et al., 2019). Only a few observational studies conducted at high latitudes (Olafsson et al., 2009; Munro et al., 2015; Wakita et al 2017) showed that the trends of DIC, $f \mathrm{CO}_{2}$ and $\mathrm{pH}$ are seasonally different and thus driven by different processes not yet fully explained. In a global context, taking into account a seasonal view for the trend analysis is also relevant to better understand the strengthening of $f \mathrm{CO}_{2}$ seasonality observed over the last 3 decades (Landschützer et al., 2018) and how this would change the degree of acidification in the future (Kwiatkowski and Orr, 2018). Note that the observed trend of $f \mathrm{CO}_{2}$ seasonality (winter minus summer) in the North Atlantic appears less pronounced than in other regions with significant subdecadal variability (see Figs. $1 \mathrm{~b}$ and $4 \mathrm{a}$ in Landschützer et al., 2018). In this context we now investigate the observed trends for winter and summer in more detail and over specific periods to quantify the effect of temperature, salinity, DIC and TA that drive the $f \mathrm{CO}_{2}$ and $\mathrm{pH}$ variations in the NASPG.

The periods 1993-1997, 2001-2007 and 2008-2017 are selected for several reasons. First, as the trends and quantification of drivers are sensitive to the data selection, we only select periods when time series for carbonate data were available (e.g., no DIC and TA data available in 1998-2000; see Table 1). This is in contrast with previous work where trends based on SURATLANT data were evaluated over 1993-2003 (Corbière et al., 2007; Metzl et al., 2010). Second, we use new binned products based on more regular SST and SSS observations (Reverdin et al., 2018a) to separate periods that present significant interannual variability and different trends in temperature and salinity (Fig. 3a, b). The three selected periods also present contrasting SST trends well identified at a regional scale in the North Atlantic, at monthly or seasonal scales (Fig. S2). Finally, in the NASPG it is well recognized that decadal and multi-decadal variability in temperature, salinity, winter convection and large-scale gyre circulation is associated with the phase of the NAO or AMO (Fig. 3c).

During the first observational period 1993-1997 (rather short), the NAO shifted from a positive to negative phase while the AMO was in a transitional stage and regularly increased during the 1990s (Fig. 3c). During the positive NAO in the early 1990s, the NASPG experienced a deep convection regime in the western subpolar gyre (Pickart et al., 2003). During the second period 2001-2007, the NAO was negative or neutral and the AMO reached a high index. The convection in the western NASPG was relatively shallow during this period and the ocean surface warmed (Fig. 3a). In the last decade, 2008-2017, the NAO was highly variable compared to previous periods, with the lowest phase in 2010 and highest phase in 2015 (Fig. 3c). Conversely, the AMO has strongly decreased since the late 2000s. During this period, both SST and SSS anomalies present clear negative trends: the NASPG becomes colder and fresher (Fig. 3a, b) during this period, also associated with several deep convection events occurring in the western subpolar gyre during the winters 2008, 2012 and 2015 (Våge et al., 2008; de Jong and de Steur, 2016; Fröb et al., 2016; Piron et al., 2017).

\subsection{Winter trends for different periods}

The trends and drivers in winter are identified as blue symbols in Figs. 4 and 5. During the first period, 19931997, the results are contrasted between the southern and northern regions. The strongest change occurs in the south (box B), where we observe a rapid cooling over 4 years $\left(-0.19^{\circ} \mathrm{C} \mathrm{yr}^{-1}\right)$, an increase in salinity $\left(+0.045 \mathrm{yr}^{-1}\right)$ and an increase in TA $\left(+2 \mu \mathrm{mol} \mathrm{kg}^{-1} \mathrm{yr}^{-1}\right)$ that is directly linked to salinity (recall that for 1993-1997 TA was not measured and the TA values are based on salinity, Eq. 1). Over this short period, this leads to a strong decrease in $f \mathrm{CO}_{2}\left(-7 \mu \mathrm{atm} \mathrm{yr}^{-1}\right)$ and an increase in $\mathrm{pH}$, both attributed to the cooling and TA changes (Fig. 5a, d), the effect of DIC being minor. In the north (boxes CDE), we do not observe any significant trend of winter properties in 1993-1997 for SST, sTA, sDIC, $\mathrm{pH}$ and $f \mathrm{CO}_{2}$. As a result, in the NASPG (all region), the oceanic $f \mathrm{CO}_{2}$ trend does not follow the atmospheric $\mathrm{CO}_{2}$ increase, and the air-sea disequilibrium increases; i.e., the region was a $\mathrm{CO}_{2}$ source in winter 1994 and reached near equilibrium afterwards (Fig. 4h).

As opposed to the $1990 \mathrm{~s}$, data collected in winter during the second period (2002-2007) show a gradual DIC increase in the two regions $\left(+1.7\right.$ and $+2.1 \mu \mathrm{mol} \mathrm{kg}^{-1} \mathrm{yr}^{-1}$, Table 2) higher than expected from the anthropogenic $\mathrm{CO}_{2}$ increase. A decrease in TA is also observed in the northern region but not directly related to salinity. This leads to a significant $\mathrm{pH}$ decrease $\left(-0.006\right.$ to $\left.-0.008 \mathrm{yr}^{-1}\right)$ and fast $f \mathrm{CO}_{2}$ increase $\left(+6\right.$ to $\left.+7 \mu \mathrm{atm} \mathrm{yr}^{-1}\right)$. For this period, the DIC increase explains the temporal changes in $\mathrm{pH}$ and $f \mathrm{CO}_{2}$ in box $\mathrm{B}$, whereas both DIC and TA drive these changes in box CDE (Fig. 5b, e). In contrast to 1993-1997, the winter oceanic $\mathrm{CO}_{2}$ source increases during 2002-2007. It is near equilibrium in 2002 and a source in 2004-2007 (Fig. 4h), a result previously confirmed with independent sea surface $f \mathrm{CO}_{2}$ observations (Metzl et al., 2010). At the end of this period, in winter 2007, oceanic $f \mathrm{CO}_{2}$ was higher than $400 \mu \mathrm{atm}$ and $\mathrm{pH}$ was low, near 8.04.

The last period, 2008-2015, was not investigated in previous studies (Corbière et al., 2007; Metzl et al., 2010). 

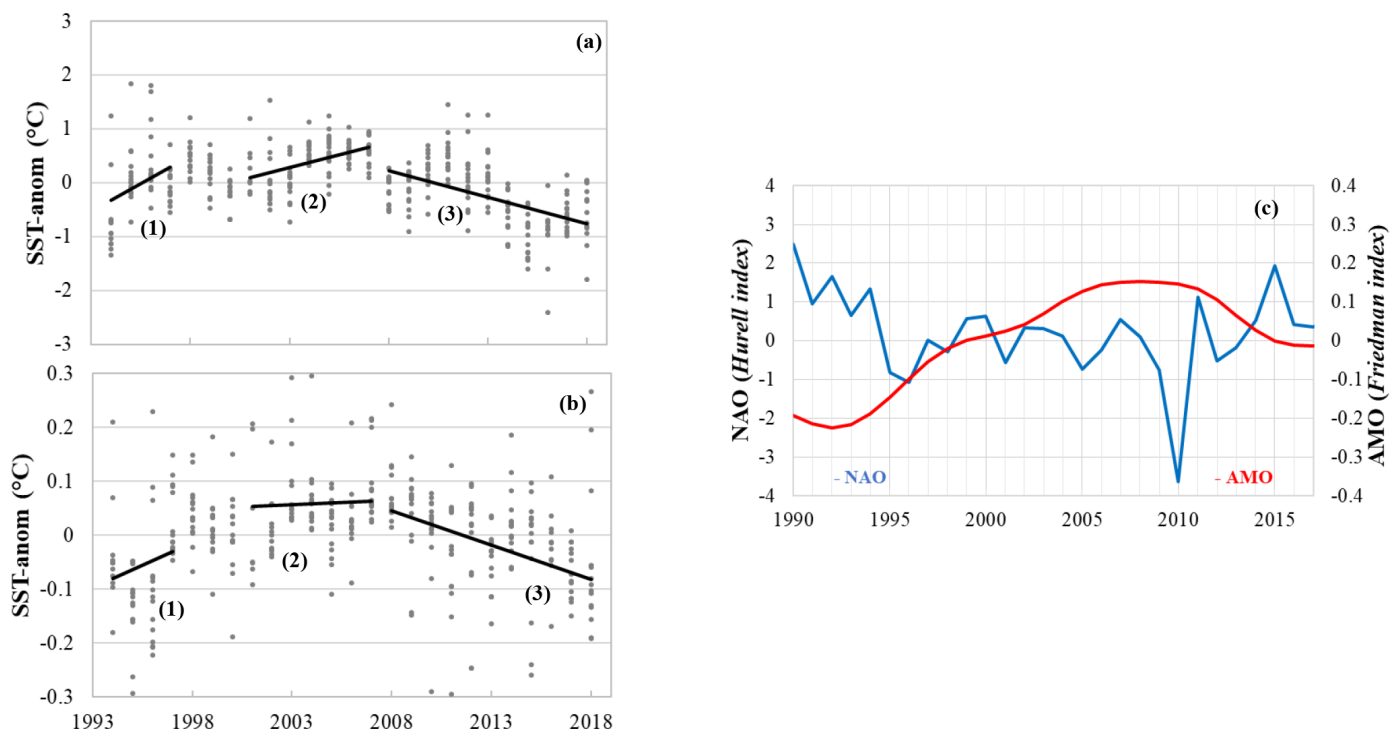

Figure 3. SST (a) and SSS (b) anomalies for winter (January-February) along the SURATLANT track (north of $50^{\circ} \mathrm{N}$ ), based on the binned products constructed by Reverdin et al. (2018a) and updated data to 2018, available at https://doi.org/10.6096/ SSS-BIN-NASG (last access: 25 March 2020). The mean trends for each period selected for the carbonate data analysis (when available) are represented as black lines (1: 1993-1997; 2: 2001-2007; 3: 2008-2017). The NAO index (in blue, Hurrell data available at https://climatedataguide.ucar.edu/climate-data/hurrell-north-atlantic-oscillation-nao-index-station-based, last access: 30 September 2019) and AMO index (in red, Friedman ERSST V5 data available at https://www.ncdc.noaa.gov/data-access/marineocean-data/ extended-reconstructed-sea-surface-temperature-ersst-v5, last access: 20 November 2019) are represented (c).

During 2008-2015, the DIC concentrations in winter continue to rise ( +1.0 to $+1.3 \mu \mathrm{mol} \mathrm{kg}^{-1} \mathrm{yr}^{-1}$, Table 2) but at a slower pace compared to previous years and still higher than the anthropogenic DIC trend. Contrary to 2001-2007, we do not observe large changes in TA. In the northern region (box CDE) the sea surface cools $\left(-0.05^{\circ} \mathrm{Cyr}^{-1}\right)$, which is not found in the southern region, inducing different $f \mathrm{CO}_{2}$ and $\mathrm{pH}$ trends in the southern and northern sectors. In the north, the low $f \mathrm{CO}_{2}$ and $\mathrm{pH}$ trends are due to a DIC increase compensated for by cooling and a small TA increase, whereas in the south the $f \mathrm{CO}_{2}$ trend $\left(+2.5 \mu \mathrm{atm} \mathrm{yr}^{-1}\right)$ and $\mathrm{pH}$ trend $\left(-0.0024 \mathrm{yr}^{-1}\right)$ are mainly driven by DIC increase (Fig. 5c, f). These trends deviate from the ones in 2001-2007 with different processes possibly related to the NAO presenting much more variability during the last period (Fig. 3c). At the end of our time series and in both regions $f \mathrm{CO}_{2}$ in winter 2015 reaches the highest value $(410 \mu \mathrm{atm})$ recorded since 1993 and the lowest $\mathrm{pH}$ values (8.03), with the same for $\Omega_{\mathrm{Ar}}$ (1.7). This is mainly explained by DIC concentrations approaching $2160 \mu \mathrm{mol} \mathrm{kg}-1$ in February 2015 (Fig. 4e). These high DIC concentrations observed in winter 2015 correspond to a high positive NAO phase (Fig. 3c) and to negative SST anomalies (Fig. 3a). It was also associated with strengthening of fresh water coming from the western NASPG (Holliday et al., 2020) and likely resulted in increased vertical mixing over the Reykjanes Ridge (De Boisséson et al., 2012). The high DIC and sDIC concentrations observed in winter 2015 are not unique to the Irminger Sea. Recently, based on sea surface $f \mathrm{CO}_{2}$ measurements conducted in winter 2004-2017 and DIC calculated from $f \mathrm{CO}_{2}$ data and reconstructed TA (using an adapted TA-SSS relation), Fröb et al. (2019) report average winter sDIC concentrations of around $2160 \mu \mathrm{mol} \mathrm{kg}-1$ in 2012 and 2014. These authors also observed high sDIC concentrations in winter 2017 , above $2165 \mu \mathrm{mol} \mathrm{kg}{ }^{-1}$. Unfortunately, we cannot compare these values as we have no winter data after 2015 along the SURATLANT line (Table 1). Although the periods are not exactly the same and methods to evaluate trends are different, the sDIC trends reported by Fröb et al. (2019) are in the same range as here: between +1.3 and $+1.75 \mu \mathrm{mol} \mathrm{kg}^{-1} \mathrm{yr}^{-1}$ for the period 2004-2017, when we find (i.e., boxes $\mathrm{CDE}$ including the eastern Irminger Sea) a sDIC trend of $+1.8 \mu \mathrm{mol} \mathrm{kg}{ }^{-1} \mathrm{yr}^{-1}$ for $2001-2007$ and $+1.3 \mu \mathrm{mol} \mathrm{kg}^{-1} \mathrm{yr}^{-1}$ for 2008-2015 (Table 2). Both results show a clear increase in SDIC in the NASPG or Irminger Sea since 2001 (or 2004), and the differences in trends might also be modulated by interannual variability.

During 2008-2015, we also observe significant interannual variability in winter, with marked DIC minima in 2010 and 2013 also found in sDIC concentrations as well as in TA and sTA (Fig. 4c-f). Interestingly, Fröb et al. (2019) also report lower sDIC concentrations in 2010 and 2013 in the Irminger Sea. In 2010, the NAO shifted to a negative phase (Fig. 3c) supporting relatively shallow convection in the NASPG and inducing positive SST anomalies (Fig. 3a); the absence of deep mixed layers during these years would 

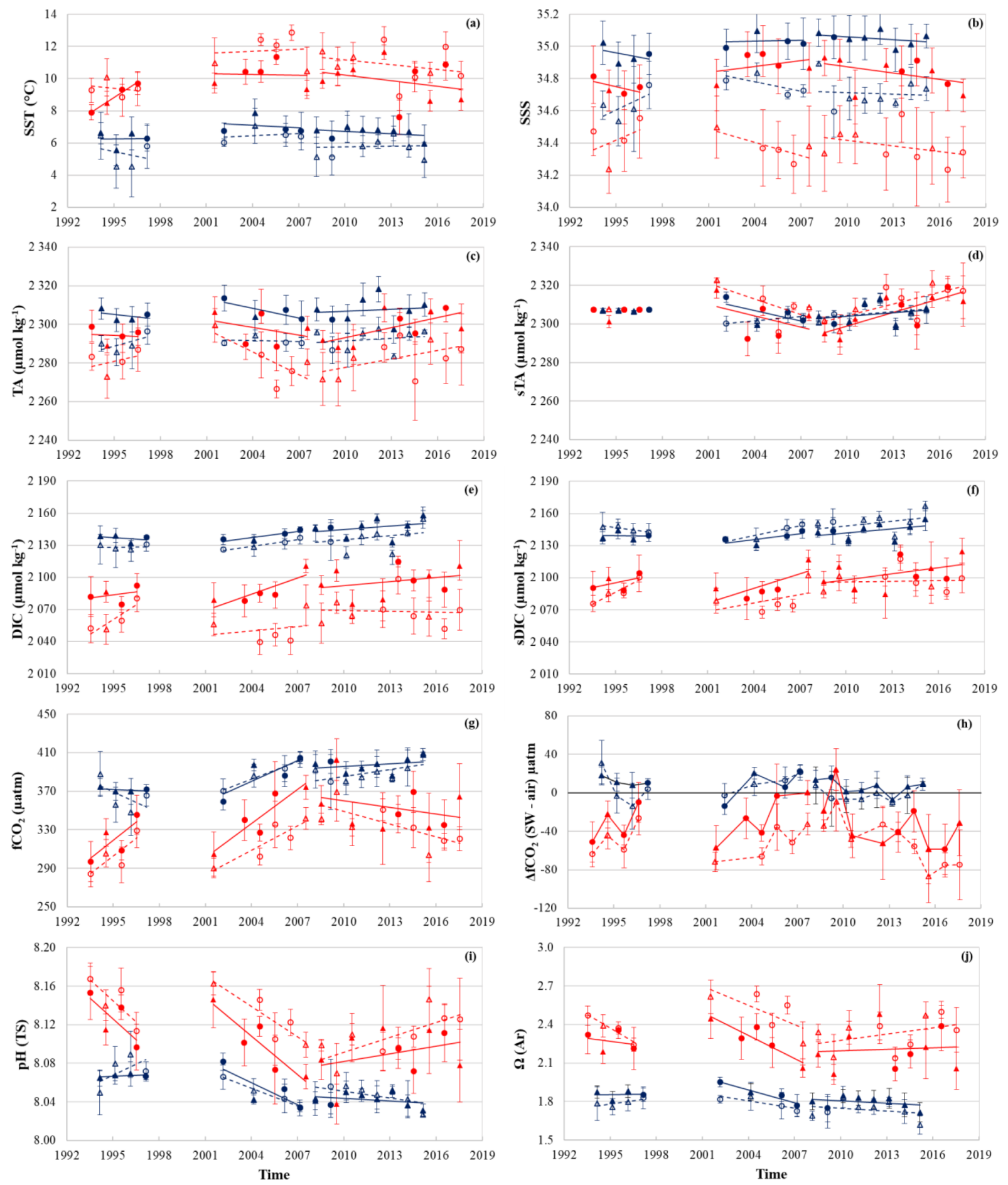

Figure 4. Evolution of (a) SST, (b) SSS, (c) TA, (d) sTA, (e) DIC, (f) sDIC, (g) $f \mathrm{CO}_{2}$, (h) $\Delta f \mathrm{CO}_{2}$, (i) $\mathrm{pH}$ and (j) $\Omega$ Ar between 1993 and 2017 is obtained in box B (open symbols) and by combining all data in boxes C, D and E (filled symbols) during summer (in red) and winter (in blue). Data from February and July are indicated with circles, and the reconstructed data are depicted with triangles. 

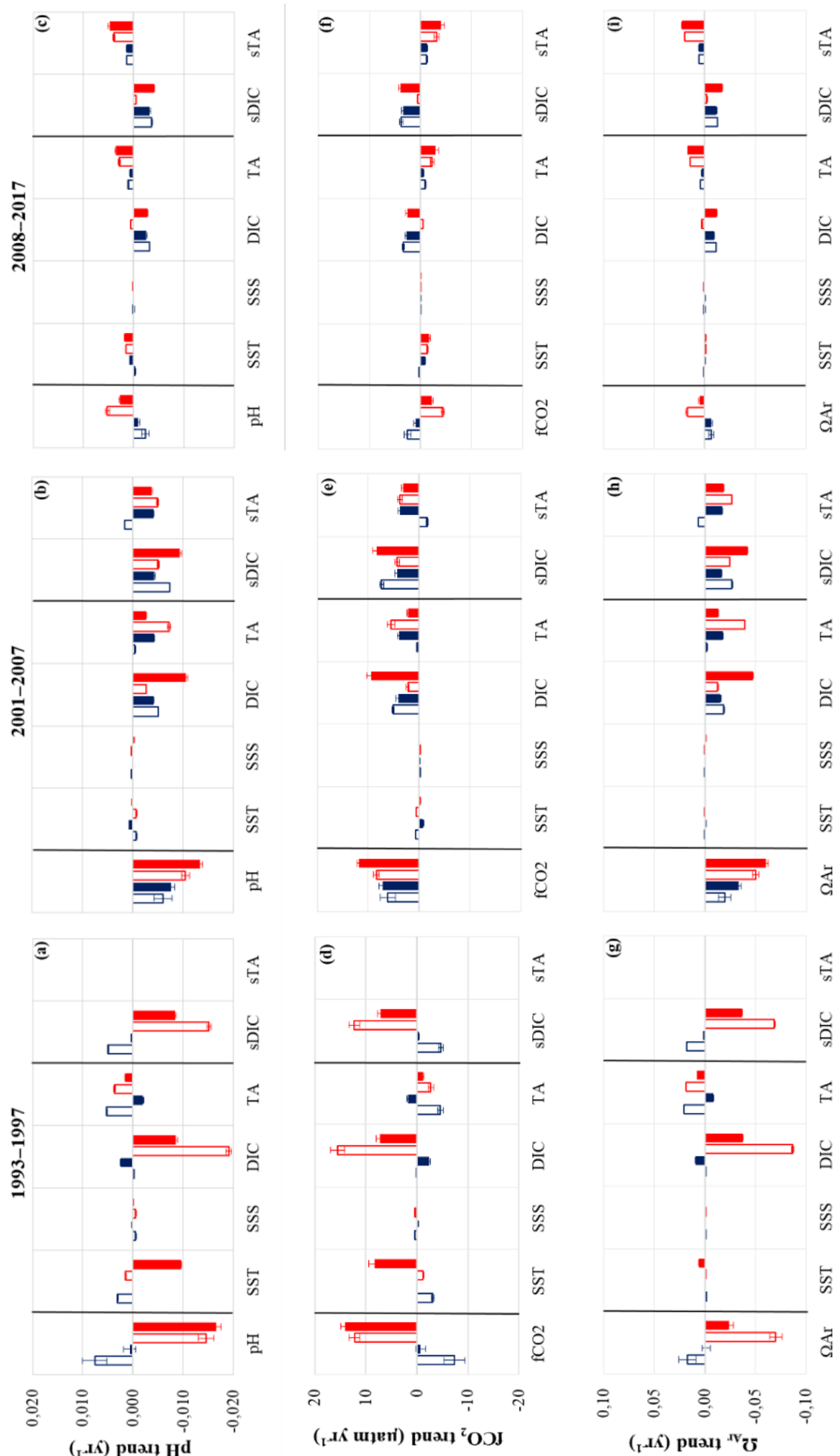

Figure 5. Decomposition of the trends in surface $\mathrm{pH}(\mathbf{a}-\mathbf{c}), f \mathrm{CO}_{2}(\mathbf{d}-\mathbf{f})$ and $\Omega \mathrm{Ar}(\mathbf{g}-\mathbf{i})$ according to Eq. (2). The effect of the changes in SSS, SST, DIC, TA and the normalized part (sDIC and sTA) is shown for the three periods: 1993-1997 (left column), 2001-2007 (middle column) and 2008-2017 (right column). Color coding is the same as in Fig. 4. Here, DIC (or TA) represents the total carbon (or total alkalinity) part, whereas sDIC (or sTA) is the part of the DIC (or TA) driver not related to salinity (see explanations for Eq. 2). 
explain the relatively low DIC and TA concentrations observed in winter (i.e., less input of high DIC and TA from subsurface layers). In 2013, although the NAO was neutral, we also observed lower DIC and TA in winter. It is suggested that mixing was relatively shallow in the Irminger Sea and near the Reykjanes Ridge in 2013, which could drive less renewal of the surface layers by the enriched sDIC deeper waters and thus negative winter DIC and TA anomalies for this particular year. However, as both DIC and TA decrease, $f \mathrm{CO}_{2}$ and $\mathrm{pH}$ do not strongly change for these particular years (2010 and 2013), and associated air-sea $\mathrm{CO}_{2}$ disequilibrium remains stable (Fig. 4h). The strong negative DIC anomalies observed in 2010 and 2013 nonetheless influence the DIC trend for the period 2008-2015: not including those 2 years increases the trend in boxes CDE from +1.0 to $+1.3 \mu \mathrm{mol} \mathrm{kg} \mathrm{gr}^{-1}$. However, this is still lower compared to 2002-2007 $\left(+1.7 \mu \mathrm{mol} \mathrm{kg}^{-1} \mathrm{yr}^{-1}\right)$, and thus a much slower trend for $f \mathrm{CO}_{2}$ and $\mathrm{pH}$ is estimated in recent years. As a result, in 2008-2015 we interpret the $f \mathrm{CO}_{2}$ and $\mathrm{pH}$ winter changes equally due to the contribution of anthropogenic $\mathrm{CO}_{2}$ (C-ant) and the natural component (DIC-nat), whereas in 2001-2007 the natural component dominates due to the dynamics in the NASPG (Fig. 6c, d).

\subsection{Summer trends for different periods}

We examine the trends and drivers in summer over the same periods selected for winter (except for the last period, with 2001-2017 in summer and 2002-2015 in winter). Results for summer are identified by the red symbols in Figs. 4 and 5. As mentioned earlier, a trend analysis in summer was not performed in previous work based on SURATLANT data (Metzl et al., 2010). Here we attempt for the first time to detect trends and processes occurring during this season and how they impact $f \mathrm{CO}_{2}$, air-sea $\mathrm{CO}_{2}$ equilibrium and $\mathrm{pH}$ changes. Not surprisingly, the temporal variability of the carbonate properties is much more pronounced during summer when biological processes generally starting in spring imprint large DIC variations at the seasonal scale (Fig. 2). The biological bloom and its timing may also lead to significant interannual variability, but, as we use July as a reference for summer, we expect to record the low DIC concentrations each year due to accumulated carbon uptake though production occurring in spring-summer.

During the first period, 1993-1996, the most remarkable feature is a very rapid increase in DIC in the northern and southern sectors $\left(+4\right.$ and $+9 \mu \mathrm{mol} \mathrm{kg}^{-1} \mathrm{yr}^{-1}$ ). This contrasts with the DIC trends in winter over 1994-1997 (Table 2). Because the northern box (CDE) also experienced a sharp warming of $+0.6^{\circ} \mathrm{Cyr}^{-1}$, there the $f \mathrm{CO}_{2}$ increase $(+12$ to

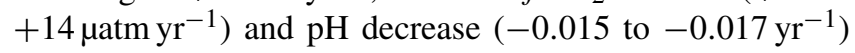
are particularly fast. However, the period is too short to clearly interpret which are the main processes at play and derive any conclusion on the trends. We notice that in 19931996, the NAO changed from a positive to negative phase and the AMO progressively increased in the 1990s (Fig. 3c), but no particular anomalies were revealed in the winter observations. Thus, we have no direct explanation for the fast DIC, $f \mathrm{CO}_{2}$ and $\mathrm{pH}$ changes observed during the summer in 1993-1996, except that relatively higher DIC in 1996 might have resulted from a decrease in primary production compared with previous years. This is rather speculative as we have no other information on nutrients or on the biological activity (e.g., no nutrient data for summer 1996 and no remote sensing data at the beginning of the 1990s). However, using continuous plankton recorder (CPR) data over 19602010 in both the western and eastern NASPG regions, Martinez et al. (2016) identified negative anomalies of Chl $a$ around 1996-1997 after a sharp increase in Chl $a$ during 1986-1995. The $f \mathrm{CO}_{2}$ data show that the region was a large $\mathrm{CO}_{2}$ sink in summer in 1993-1995 but abruptly increased to near-equilibrium values in 1996 (Fig. 4h). In the northern region (box $\mathrm{CDE}$ ), the mean delta- $f \mathrm{CO}_{2}$ value in summer 1996 was close to $0 \mu \mathrm{atm}$, i.e., about the same as observed during the winter in 1996-1997.

The SURATLANT regular sampling for DIC, TA and nutrients was restarted in June 2001 (Table 1). During 20012007, and as in summer in 1993-1996, we observe a rapid increase in $f \mathrm{CO}_{2}\left(+8\right.$ to $\left.+12 \mu \mathrm{atm} \mathrm{yr}^{-1}\right)$ and $\mathrm{pH}$ decrease $\left(-0.010\right.$ to $\left.-0.013 \mathrm{yr}^{-1}\right)$. Despite having reconstructed July from the data obtained in August (for boxes B and CDE) for both the starting (2001) and ending (2007) years, this result is fairly robust. Indeed, if we do not normalize summer to July, but directly include the June-July-August data, we also observe a rapid increase in $f \mathrm{CO}_{2}$ of $+6.2 \mu \mathrm{atm} \mathrm{yr}^{-1}$. The summer DIC and TA trends in the northern and southern areas have the same sign (similar to during winter), positive for DIC and negative for TA but not directly related to salinity (Table 2). However, the DIC increasing and TA decreasing rates are regionally significantly different. The DIC increase is most pronounced in the north $\left(+5 \mu \mathrm{mol} \mathrm{kg}^{-1} \mathrm{yr}^{-1}\right)$, and the TA decrease is more pronounced in the south $\left(-3.9 \mu \mathrm{mol} \mathrm{kg} \mathrm{kg}^{-1}\right)$. Although the $f \mathrm{CO}_{2}$ and $\mathrm{pH}$ trends are similar in the two areas, this suggests different drivers for boxes B and CDE (Fig. 5b, e). In the north, DIC explains most of the $f \mathrm{CO}_{2}$ and $\mathrm{pH}$ change, whereas in the south the TA contribution dominates. In both regions, as in winter, temperature and salinity changes have a small effect for this period (Fig. 5b, e). The rapid oceanic $f \mathrm{CO}_{2}$ increase strongly impacts the variations in air-sea $\mathrm{CO}_{2}$ disequilibrium (Fig. 4h). In the north, the region was a sink in 2001-2004 but reaches equilibrium in 2005 and 2007 (no data in July 2006 in the north). In July 2007, temperature was relatively low (around $10^{\circ} \mathrm{C}$ ) and the high $f \mathrm{CO}_{2}$ at that period was mainly due to high DIC concentrations linked to low productivity that year.

For the last period, 2008-2017, results in summer are very different compared with previous decades as we now observe a decrease in $f \mathrm{CO}_{2}$ and an increase in $\mathrm{pH}$ in both regions (Fig. 4g, i; Table 2). This also contrasts with the win- 
ter trends in 2008-2015. The variation in $f \mathrm{CO}_{2}$ leads to a strong ocean $\mathrm{CO}_{2}$ sink with low delta- $f \mathrm{CO}_{2}$ in $2010-2017$ ( -40 to $-80 \mu$ atm, Fig. 4 h). During the summer in $2008-$ 2017 sea surface properties are very variable and this might be related to the NAO variability in this period (Fig. 3c) but also to changes in the ship's route in some years or to productivity occurring at the mesoscale. This was the case in July 2013 where the sampling took place further northwest (Fig. 1), impacting SST (colder, Fig. 4a) and DIC (stronger, Fig. 4e, f). However, these anomalies are less noticeable for $f \mathrm{CO}_{2}$ and pH (Fig. $4 \mathrm{~g}$, i) because the effects of SST and DIC partially compensate. Thus, we chose to not consider July 2013 for calculating trends and drivers.

Although the interannual variability is large in summer, the trends are evaluated over the period 2008-2017 using all available data (except July 2013). For this period all terms (SST, DIC and TA) contribute to the $f \mathrm{CO}_{2}$ and $\mathrm{pH}$ changes (Fig. 5c, f). The DIC increase is only revealed in the north (box CDE, $+1.2 \mu \mathrm{mol} \mathrm{kg}^{-1} \mathrm{yr}^{-1}$ ); this is slightly higher than in winter $\left(+1.0 \mu \mathrm{mol} \mathrm{kg} \mathrm{gr}^{-1}\right)$ and thus higher than anthropogenic signal (around $+0.6 \mu \mathrm{mol} \mathrm{kg}{ }^{-1} \mathrm{yr}^{-1}$ ). However, as the surface ocean cools $\left(-0.11^{\circ} \mathrm{C} \mathrm{yr}^{-1}\right)$ and TA increases $\left(+1.7 \mu \mathrm{mol} \mathrm{kg}{ }^{-1} \mathrm{yr}^{-1}\right)$, the net effect is a decrease in $f \mathrm{CO}_{2}$ $\left(-2.3 \mu \mathrm{atm} \mathrm{yr}^{-1}\right)$ and increase in $\mathrm{pH}\left(+0.0026 \mathrm{yr}^{-1}\right)$. During 2008-2017, the progressive cooling in the NASPG, found here in both winter and summer data (Fig. 4a) is a largescale signal (Fig. 3a, Robson et al., 2016; Reverdin et al., 2018a). An intriguing signal in 2008-2017 is the increase in TA (Fig. 4c) opposed to the decease in salinity (Fig. 3e, Fig. 4b); this leads to a positive sTA trend opposite to summer in 2001-2007. Therefore, we cannot interpret the observed TA increase directly linked to salinity. The shift of the sTA trend, negative in 2001-2007 and positive in 2008-2017, is an important signal that drives opposite trends for $f \mathrm{CO}_{2}$ and $\mathrm{pH}$ between the two periods (Fig. 5b, c, e, f).

This contrasting TA signal in summer cannot be attributed to error or drift in laboratory analyses as the measurements were performed using the same methods for the whole time series (Reverdin et al., 2018b), and no such signal is identified for winter cruises in 2008-2015. In addition, during OVIDE cruises conducted in summer in 2006-2014 in the North Atlantic (e.g., García-Ibáñez et al., 2016), we performed regular TA and DIC intercomparisons with the ICM/CSIC group in Vigo (F. Pérez) and certified our results to within around $\pm 4 \mu \mathrm{mol} \mathrm{kg}{ }^{-1}$ for both TA and DIC. Results based on the surface TA samples measured at LOCEAN for the OVIDE cruises in summer in 2006-2018 (data in Metzl et al., 2018) also suggest that sTA increases in the NASPG at a rate of around $+1.5 \mu \mathrm{mol} \mathrm{kg} \mathrm{kg}^{-1}$.

To support these results, we have evaluated sTA trends in the NASPG from independent data available in the most recent GLODAPv2.2019 version (Olsen et al., 2019). For this we selected the data in the layer $0-20 \mathrm{~m}$ for all cruises conducted in June-August in 1997-2014. We found a significant difference of sTA trends during this period: $-0.52 \mu \mathrm{mol} \mathrm{kg}{ }^{-1} \mathrm{yr}^{-1}$ in 1997-2006 against $+0.54 \mu \mathrm{mol} \mathrm{kg} \mathrm{kr}^{-1} \mathrm{yr}^{-1}$ in 2006-2014. Although the periods are not exactly the same and sTA trends from GLODAPv2.2019 are smaller than those deduced from the SURATLANT time series, the changing sTA trends from negative to positive in recent years are also features in that dataset. We are thus confident with TA data over time and need to find a process that explains why the sTA trend was negative in summer in 2001-2007 $\left(-1.9 \mu \mathrm{mol} \mathrm{kg}^{-1} \mathrm{yr}^{-1}\right)$ and positive in summer in $2008-2017$ $\left(+2.3 \mu \mathrm{mol} \mathrm{kg} \mathrm{yr}^{-1}\right)$.

The variability of calcification through the production of calcifying species (e.g., coccolithophores, foraminifera) is a possible mechanism that would impact TA trends as suggested by Wakita et al. (2017) in the Pacific Western Subarctic Gyre. In the northeast Atlantic, long-term in situ continuous plankton recorder (CPR) observations showed a significant increase in the calcifying species starting in the mid1990s (Beaugrand et al., 2013). These authors suggest that the temperature (a warming) was the main driver of the positive trend of calcifying plankton. In addition they show that no correlation was identified between the NAO and species variability but that a positive trend of the calcifying species was correlated with the AMO, a result also confirmed by Rivero-Calle et al. (2015). The TA decrease in summer we observe during the period 2001-2007 after the AMO moved to its positive state (Fig. 3c) might be explained by the increase in calcifying species as identified from in situ CPR observations in the North Atlantic (Beaugrand et al., 2013; Rivero-Calle et al., 2015). Unfortunately, we do not yet have direct in situ observational evidence of a reduced calcifying species after 2010. However, if one follows the proposed scenario for 2001-2017, the TA increase in summer in 20082017 during the cooling phase in the NASPG could be linked to a weakening of calcification. In this region, this seems supported by the absence of coccolithophore blooms in recent years (2010-2017) as identified from remote-sensing reflectance records (Loveday and Smyth, 2018).

\section{Discussion}

Our observations collected over the last 3 decades show an abrupt change in the evolution of hydrological and biogeochemical properties in the NASPG around the year 2007 (Fig. 4) when the AMO reached a maximum and the NAO was around neutral (Fig. 3c). Following a warming since the mid-1990s, the region experienced a large cooling and freshening after 2005 (Fig 3a, b; Robson et al., 2016; Holliday et al., 2020). This change is associated with an increase in the size of the gyre and increased currents along the gyre's southern rim (Chafik et al., 2014, 2019; Desbruyères et al., 2015), as well as by a very large heat loss during positive NAO years, particularly in 2015 (Fig. 3c, Josey et al., 2018). Indeed, the NAO was previously recognized as a possible 

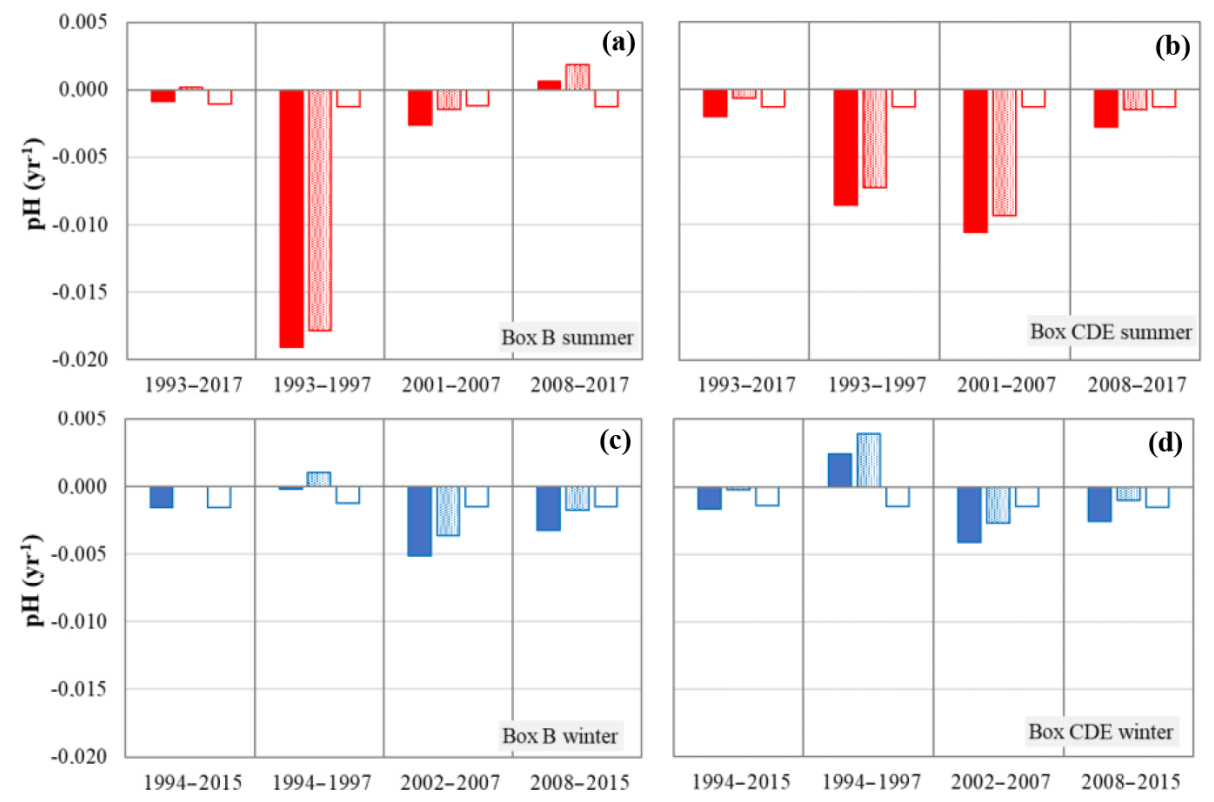

Figure 6. Decomposition of the trends in surface $\mathrm{pH}$ according to the effect of the changes in DIC-tot (filled), DIC-nat (dotted) and C-ant (open) during summer (a, b) and winter (c, d) for the long-term period and the three periods.

cause of the rapid $f \mathrm{CO}_{2}$ increase when the NAO shifted from the positive to negative phase in 1995-1996 (Fig. 3c; Corbière et al., 2007). However, this was not confirmed for the period 2001-2007 when the NAO did not vary so much around a neutral value (Fig. 3c; Metzl et al., 2010). For the whole NA, Schuster et al. (2009) synthesized $f \mathrm{CO}_{2}$ observations over 1990-2006, i.e., before 2007 when we observe abrupt changes in property trends. North of $45^{\circ} \mathrm{N}$, Schuster et al. (2009) evaluate a trend of $f \mathrm{CO}_{2}$ exceeding $+3 \mu \mathrm{atm} \mathrm{yr}^{-1}$ and a significant decrease in the $\mathrm{CO}_{2}$ sink in the NA by over $50 \%$ between 1990 and 2006. They also predict an increasing sink in the subpolar regions following the increasing NAO index in 2007. Although the impact of the climatic modes (NAO and/or AMO) on the oceanic physical properties and circulation has been well established, their effects, if any, on the $f \mathrm{CO}_{2}$ and $\mathrm{pH}$ trends need to be clarified.

Whatever the NAO variability, the long-term $f \mathrm{CO}_{2}$ and pH trends we evaluate over 1993-2017 in the NASPG for summer or winter are mainly explained by the increase in DIC associated with the uptake of anthropogenic $\mathrm{CO}_{2}$ (Fig. 6); that is, the DIC or sDIC trends (Table 2) are not significantly different from the anthropogenic DIC trend estimated between 1994 and 2007 in this region (Gruber et al., 2019a). For $f \mathrm{CO}_{2}$, here calculated from DIC-TA pairs, the long-term trends between +1.5 and $+1.7 \mu \mathrm{atm} \mathrm{yr}^{-1}$ in the NASPG (Table 2) are slightly higher than the mean trend of $+1.47( \pm 0.06) \mu \mathrm{atm} \mathrm{yr}^{-1}$ evaluated for 1992-2014 in the whole NA (Lebehot et al., 2019) based on monthly reconstructed $f \mathrm{CO}_{2}$ using a multiple linear regression (MLR) approach and SOCAT v4 $f \mathrm{CO}_{2}$ data (Bakker et al., 2016). Lebehot et al. (2019) show that the $f \mathrm{CO}_{2}$ trends based on ob- servations are much lower than those derived from 19 ESM CMIP5 models, $+1.90( \pm 0.09) \mu \mathrm{atm} \mathrm{yr}^{-1}$. By performing several sensitivity test analyses on the ocean ESMs, Lebehot et al. (2019) conclude that the discrepancy between observed and simulated $f \mathrm{CO}_{2}$ trends originates mainly in the model's biogeochemistry, e.g., biases in simulated TA and also related to the way ESMs do or do not represent winter mixing (Goris et al., 2018). This might be especially relevant for the NA subpolar region where some ESMs project faster change in ocean $f \mathrm{CO}_{2}$ in the future (2061-2100) with $60 \%$ due to the DIC increase and up to $29 \%$ due to the TA changes (Tjiputra et al., 2014). We also suspect that ESMs used to predict future change of the oceanic $\mathrm{CO}_{2}$ sink and ocean acidification would produce faster $\mathrm{pH}$ trends than what we observed.

If the long-term $f \mathrm{CO}_{2}$ and $\mathrm{pH}$ trends could be mainly explained by anthropogenic $\mathrm{CO}_{2}$ uptake in the NASPG, at shorter timescales (4-10 years) the trends are very different (Table 2). Indeed, the gradual changes in $f \mathrm{CO}_{2}$ and $\mathrm{pH}$ caused each year by the uptake of anthropogenic $\mathrm{CO}_{2}$ can be significantly masked by the natural variability of DIC (DICnat), temperature and/or TA. To better identify when and why the DIC-nat dominates, we separately compute the impact of anthropogenic $\mathrm{CO}_{2}$ (C-ant) and DIC-nat on $\mathrm{pH}$ and $f \mathrm{CO}_{2}$ trends for each season and period. The results for $\mathrm{pH}$ are presented in Fig. 6. The same results are obtained for $f \mathrm{CO}_{2}$ (not shown), with an opposite sign for each bar plotted in Fig. 6. For C-ant we adopt a value of $+0.6 \mu \mathrm{mol} \mathrm{kg}^{-1} \mathrm{yr}^{-1}$ as described in Sect. 3.2.

For all sub-periods and both seasons, the effect of DIC-nat on $\mathrm{pH}$ trend is significant and with similar or higher mag- 
nitude than the effect of C-ant (Fig. 6). Occasionally it opposes $\mathrm{C}$-ant, i.e., DIC-nat decreases with a positive effect on pH trend (box B, 2008-2017 in summer, Fig. 6a, and box CDE, 1994-1997 in winter, Fig. 6d). Over 1993-1997 the DIC-nat effect on $\mathrm{pH}$ trends for this short period is opposed in summer and winter, suggesting that this is not linked to changes in regional circulation, e.g., less or more input of DIC from different water masses. For 1993-1997 when the largest DIC-nat effect is observed in summer (in the northern and southern boxes), one might suggest that it is linked to primary productivity; unfortunately, prior to SeaWiFS in 1998, we have no direct or indirect information on biological changes to explain why DIC-nat increased in summer in 1993-1997. However, the length of the period is short and trend results are very sensitive to interannual anomalies, especially in the first and last years.

Apart from the first short period (1993-1997), the largest effect of DIC-nat is observed in summer in 2001-2007 in the northern region (Fig. 6b). This period includes a decade (1995-2005) where the strength of the subpolar gyre circulation decreased (Häkkinen and Rhines, 2004, 2009; Häkkinen et al., 2011, 2013), suggesting that more water of subtropical origin penetrates the NASPG. This would have decreased the DIC surface concentrations (and increase TA as well), but for 2001-2007 we observed the opposite, including in winter (Table 2). We thus eliminate the effect of advection to interpret the DIC-nat increase in the NASPG that impacts $\mathrm{pH}$ trend significantly. As mixed-layer depths are not deeper than 30-40 $\mathrm{m}$ in summer and present no significant interannual changes (according to the dataset Armor which presents the same variations as the data of the product GLOBAL-REANALYSIS-PHY-001 030 distributed on http://marine.copernicus.eu/, last access: 28 October 2019), the variation in the vertical mixing during this season is not a likely candidate to explain the changes in DIC-nat. A possible explanation for the large contribution of DICnat to $\mathrm{pH}$ (and $f \mathrm{CO}_{2}$ ) in 2001-2007 could be a decline in biomass identified in SeaWiFS data in the eastern subpolar region for the years 1998-2007, although the trends for net primary productivity (NPP) appear to not be statistically significant over 10 years (McKinley et al., 2018). For the NPP subject to high-frequency variability, the evaluation of trends over nearly 10 years is challenging. Annual biomass anomalies (based on SeaWiFS and MODIS sensors) changed from positive values in 1998-2004 to negative ones in 2005-2009 (McKinley et al., 2018). To explain the biomass decline, McKinley et al. (2018) used a coupled physical-biogeochemical ocean model (OBGM) to reproduce these changes and found that nutrient concentrations decline significantly in the region north of $50^{\circ} \mathrm{N}$ due to reduced physical supply through horizontal and vertical fluxes; their model suggests that enhanced phosphate and silicate limitation over time dominates the light limitation in this region.

Due to limited sampling months and the high variability of nutrients in spring-summer, we have not been able to detect such a mechanism from the SURATLANT nutrient data. However, the reduced productivity due to nutrient limitations (McKinley et al., 2018) is supported by independent observations of silicate concentrations in the subpolar NA over 25 years (McKinley et al., 2018). They showed a decline in pre-bloom silicate concentrations in the winter mixed layer since the 1990s until 2010 and attributed it to the decrease in winter convection depth and the weakening of the NASPG. This decline of silicates observed over 25 years would negatively impact diatom blooms in spring and favor coccolithophore blooms occurring in summer. Such a scenario is coherent with the increase in calcifying species since the mid-1990s as observed from the CPR data in the NA during a warm period associated with the AMO (Beaugrand et al., 2013; Rivero-Calle et al., 2015). The shift of phytoplankton species and local or regional intensified calcification might also explain the low sTA concentrations occasionally observed in 2003 and 2005, i.e., lower than for summer 2001 and also for winter (Fig. 4d). The interannual variability of TA of around $\pm 8 \mu \mathrm{mol} \mathrm{kg}-1$ in 2001-2007 is twice the TA change of $\pm 4 \mu \mathrm{mol} \mathrm{kg}{ }^{-1}$ due to coccolithophores in a biological model applied at $60^{\circ} \mathrm{N}-30^{\circ} \mathrm{W}$ (Signorini et al., 2012). The TA and sTA negative trends observed in 20012007 (Table 2) contribute less to $\mathrm{pH}$ and $f \mathrm{CO}_{2}$ trends than with DIC (Fig. 5b, e) but nearly the same magnitude compared to the contribution of $\mathrm{C}$-ant. This is not the case after 2007.

During the last decade, 2008-2017, observations were obtained during a strong negative NAO in 2010 and a positive NAO phase in 2015 (Fig. 3c). The NAO presents large interannual variation compared to 1995-2007 (Fig. 3c) and a decline in AMO index after 2010 (Fig. 3c). The 2010 event was associated with a warming and freshening (Fig. 4a, b) found in both SURATLANT discrete sampling (in August 2010) and monthly reconstructed binned products (Reverdin et al., 2018a). In August 2010 the DIC concentrations were very low in the north $\left(<2070 \mu \mathrm{mol} \mathrm{kg}{ }^{-1}\right)$ compared with other years since 1993 (Fig. 4e). This was not associated with particular signals in TA but with high $\delta^{13} \mathrm{C}_{\mathrm{DIC}}$ as reported in Racapé et al. (2014) and also with higher Chl $a$ concentration identified from MODIS data (McKinley et al., 2018). Indeed, Henson et al. (2013) showed that the physical forcing caused by the very negative NAO recorded in winter 2009-2010 stimulated spring blooms and not the eruption of the volcano Eyjafjallajökull in Iceland, which erupted in spring 2010, depositing large amounts of iron in the North Atlantic Subpolar region. The effect of the higher productivity in summer 2010 is due to lower $f \mathrm{CO}_{2}$ and increased $\mathrm{pH}$ compared to previous summers. Thus, there was a rapid drop in delta- $f \mathrm{CO}_{2}$ in 2009-2010, such that summer 2010 was a strong $\mathrm{CO}_{2}$ sink. In 2015, when the $\mathrm{NAO}$ was in a positive phase, the SST anomaly was on the order of $-1{ }^{\circ} \mathrm{C}$ (Fig. 3a): for that year, DIC was high in winter, close to the maximum observed in winter in our time series (Fig. 4e, f). As the temperature also lowers $f \mathrm{CO}_{2}$, the $f \mathrm{CO}_{2}$ values (and 
$\mathrm{pH})$ were not so different from other winters, illustrating the competing effects of cooling and deeper vertical mixing on $f \mathrm{CO}_{2}$. Although significant changes are observed for DIC variability during NAO events in 2010 and 2015, they seem to have a small impact on the trends. After 2007 the positive DIC trends are less important than in 2001-2007 (Table 2) and the contributions of the natural and anthropogenic parts of DIC have a similar magnitude in summer and winter (Fig. 6). This result alone does not explain the decrease in $f \mathrm{CO}_{2}$ and the increase in $\mathrm{pH}$ observed during the last period in summer. Indeed, there is also a significant impact of cooling and, as opposed to 2001-2007, an intriguing increase in TA, both leading to decreasing $f \mathrm{CO}_{2}$ and increasing $\mathrm{pH}$ trends (Figs. 4, 5).

\section{Conclusion and perspectives}

Based on sea surface observations of DIC and TA collected in the NASPG over 1993-2017, we have analyzed the variability and trends of the carbonate system properties including $f \mathrm{CO}_{2}, \mathrm{pH}, \Omega_{\mathrm{Ar}}$ and $\Omega_{\mathrm{Ca}}$ calculated from the DIC-TA pairs. This study extends to summer, and for $\mathrm{pH}$ and $\Omega_{\mathrm{Ar}}$ there is previous work based on winter data (Corbière et al., 2007; Metzl et al., 2010). It also extends the analysis for the last decade, 2008-2017, after the AMO reached a maximum and then decline and when the NAO was highly variable.

In the last decade we observed a continuous surface DIC increase in winter in the northern and southern NASPG. In February 2015 when the NAO was in a positive state, DIC reached a maximum concentration (DIC $>2150 \mu \mathrm{mol} \mathrm{kg}{ }^{-1}$, i.e., more than $+20 \mu \mathrm{mol} \mathrm{kg}{ }^{-1}$ higher than in the $1990 \mathrm{~s}$ ). In $2015 \mathrm{pH}$ was at a minimum (8.03), and $f \mathrm{CO}_{2}$ exceeded $400 \mu \mathrm{atm}$ and was close to the atmospheric $f \mathrm{CO}_{2}$. Such high $f \mathrm{CO}_{2}$ was also observed in the NASPG in January-February 2015 from direct underway measurements (range 405-415 $\mu \mathrm{atm}$ for cruises AGFO20150115 and AGFO20150212 (measured by Wanninkhof NOAA/AOML on the MV Skogafoss) in SOCAT v5; Bakker et al., 2016). As opposed to the wintertime DIC continuous increase observed since the 1990s, the TA decadal variability is not uniform. In 2001-2007 the decreasing TA, added to the DIC changes, reinforced a rapid $f \mathrm{CO}_{2}$ increase of up to $+7 \mu \mathrm{atm} \mathrm{yr}{ }^{-1}$ and a strong $\mathrm{pH}$ decline of around $-0.007 \mathrm{yr}^{-1}$ confirming previous studies (Metzl et al., 2010). Conversely, in 2008-2015 the increasing TA and the cooling in the northern NASPG compensated for the effect of DIC increase, leading to much smaller winter trends for $f \mathrm{CO}_{2}$ and $\mathrm{pH}$, on the order of $+1 \mu \mathrm{atm} \mathrm{yr}^{-1}$ and $-0.001 \mathrm{yr}^{-1}$, respectively.

During summer, the interannual variability of all properties is much more pronounced due to active primary productivity in the NASPG in spring-summer and shallow mixed layers. Consequently, the decadal trends of the carbonate system properties in summer are more difficult to detect compared with winter or other oceanic regions such as the sub- tropics (Bates et al., 2014; Ono et al., 2019). In addition, primary production often occurs at small spatiotemporal scales, and the DIC-TA heterogeneous sampling may have occasionally missed planktonic blooms. In 2001-2007 the summer trends of SST, DIC and TA have the same sign as in winter. This confirms the fast increase in $f \mathrm{CO}_{2}$ and the strong decline of $\mathrm{pH}$ observed during this period. The natural variability of DIC dominates the effect of the anthropogenic uptake on $f \mathrm{CO}_{2}$ and $\mathrm{pH}$ trends, especially in the northern region (Fig. 6). The DIC increase in summer is likely due to a reduced productivity during this period (Tilstone et al., 2014; McKinley et al., 2018). After 2007, the $f \mathrm{CO}_{2}$ and $\mathrm{pH}$ trends for summer are drastically different from the previous decade. In both southern and northern parts of the transect, the $f \mathrm{CO}_{2}$ trend becomes negative while the $\mathrm{pH}$ trend is positive (up to $+0.0052 \mathrm{yr}^{-1}$ in the south). This is driven by a complex interplay of cooling $\left(-0.1^{\circ} \mathrm{C} \mathrm{yr}^{-1}\right)$, DIC increase and significant increase in TA more pronounced in summer than in winter.

Before 2007, we evaluate a rapid $f \mathrm{CO}_{2}$ increase faster than in the atmosphere. As a result, the ocean $\mathrm{CO}_{2}$ uptake decreased in the NASPG from 1993 to 2007, in agreement with other studies (Schuster et al., 2009; Landschützer et al., 2013). However, at larger scale, here for the NA-SPSS regional biome (Fay and McKinley, 2014), the decreasing $\mathrm{CO}_{2}$ sink in the NASPG for this period is not always resolved from $f \mathrm{CO}_{2}$ data-based methods that evaluate an increasing $\mathrm{CO}_{2}$ sink in the North Atlantic Subpolar region (Rödenbeck et al., 2015; Denvil-Sommer et al., 2019). This disagreement might be in part due to missing $f \mathrm{CO}_{2}$ data for the period 1994-2003 in the NASPG (Bakker et al., 2016) and need to be investigated in further studies. After 2007, our results show that winter $f \mathrm{CO}_{2}$ increased at a lower rate than in the atmosphere, whereas in summer we observe a decrease in $f \mathrm{CO}_{2}$. Thus, the ocean $\mathrm{CO}_{2}$ sink increases over 2008-2017 (Fig. 4h). For this period this is coherent with the results derived from data-based methods in the NA-SPSS biome but only for 2007-2013. Indeed after 2013 the indirect methods produce either an increasing $\mathrm{CO}_{2}$ sink or a decreasing $\mathrm{CO}_{2}$ sink and with a very high variability noticeable in 2015 when the NAO was positive (four indirect methods present in Fig. S5h in Denvil-Sommer et al., 2019).

The observed change in all sea surface properties around 2007 in the NASPG, as well as a decreasing $\mathrm{CO}_{2}$ sink before 2007 and an increasing $\mathrm{CO}_{2}$ sink after 2008 (Fig. 4h), seems linked to the AMO rather than directly to the NAO (Fig. 3c) as also suggested by data-based reconstructed $f \mathrm{CO}_{2}$ fields in the North Atlantic (Landschützer et al., 2019).

The temporal change in $f \mathrm{CO}_{2}$ and $\mathrm{CO}_{2}$ uptake around 2007 that we deduce from SST, DIC and TA is also clearly observed in $\mathrm{pH}$ variability. In summer, the rapid $\mathrm{pH}$ decline in 2001-2007 is followed by a significant $\mathrm{pH}$ increase in 2008-2017. This is due to a changing trend in TA that was negative before 2007 and positive after 2008, a signal observed in both seasons. This unexpected decadal change in 
TA, also observed in the northwestern subpolar Pacific, might be linked to changes in calcification processes (Wakita et al., 2017). Indeed, it has been recognized that calcifying species in the North Atlantic present significant variations since the mid-1990s (Beaugrand et al., 2013). Quantification of how this process impacts $f \mathrm{CO}_{2}$ and $\mathrm{pH}$ variability deserves further studies to investigate the coupling of chemical measurements with species observations such as those obtained from CPR in the NASPG.

Although we identified significant interannual to decadal variability in surface carbonate system properties over the full time series (1993-2017), the long-term trends of $f \mathrm{CO}_{2}$ and $\mathrm{pH}$ in winter and summer are almost entirely explained by the DIC increase and anthropogenic $\mathrm{CO}_{2}$ uptake (Fig. 6). The long-term trend of $f \mathrm{CO}_{2}$ in the NASPG (between +1.5 and $\left.+1.7 \mu \mathrm{atm} \mathrm{yr}^{-1}\right)$ is slightly higher than the mean trend for 1992-2014 (+1.47 $\left.\mu \mathrm{atm} \mathrm{yr}^{-1}\right)$ evaluated at a large scale in the NA (Lebehot et al., 2019). Our results now extended to 2017 confirm the $f \mathrm{CO}_{2}$ trends evaluated by McKinley et al. (2011) for the period 1981-2009, and our new estimate for $1993-2017$ in summer $\left(+1.7 \mu \mathrm{atm} \mathrm{yr}^{-1}\right)$ is not significantly different from the trend of $+1.8 \mu \mathrm{atm} \mathrm{yr}^{-1}$ estimated for 1981-2002 based on a few observations in August (Corbière et al., 2007). However, it is worth noting that in other NA sectors and periods, such a $f \mathrm{CO}_{2}$ increase is not always observed. In a recent study focused on the midlatitude NA (40$50^{\circ} \mathrm{N}$ ), Macovei et al. (2019) showed that $f \mathrm{CO}_{2}$ is highly variable with a small trend of $+0.37( \pm 0.22) \mu a \mathrm{~atm}^{-1}$ in 2002-2016, implying a significant increase in the $\mathrm{CO}_{2}$ uptake in this region, especially after 2010 when we also observed a sudden drop of $f \mathrm{CO}_{2}$ in summer in the NASPG (Fig. $4 \mathrm{~g}, \mathrm{~h}$ ). Our results added to those from Macovei et al. (2019) suggest the ocean $\mathrm{CO}_{2}$ sink increased in the North Atlantic (north of $40^{\circ} \mathrm{N}$ ) at least since 2007 and until 2017, contributing to the increase in the global ocean $\mathrm{CO}_{2}$ sink (Friedlingstein et al., 2019). At the NA basin scale this is consistent with results deduced from $f \mathrm{CO}_{2}$ reconstructed databased methods (Denvil-Sommer et al., 2019; Gregor et al., 2019) but opposed to the ocean $\mathrm{CO}_{2}$ sink variability generated by current ESMs, suggesting uncertainties for predicting the evolution of the $\mathrm{NA} \mathrm{CO}_{2}$ sink in the future (Lebehot et al., 2019).

For $\mathrm{pH}$ the long-term trend in the NASPG of $-0.0017 \mathrm{yr}^{-1}$ is in the range of what is observed in other oceanic regions but we note some differences. This trend is equal to the trend estimated at BATS station but is lower than in the Irminger Sea and higher than in the Iceland Sea (Bates et al., 2014). It is also lower than the $\mathrm{pH}$ trend of $-0.0020 \mathrm{yr}^{-1}$ estimated in the North Atlantic Subpolar region in 1991-2011 (Lauvset et al., 2015) and $-0.0024 \mathrm{yr}^{-1}$ recently observed in the NA waters in the North Sea in 2004-2015 (Omar et al., 2019).

Given the large differences of $f \mathrm{CO}_{2}$ and $\mathrm{pH}$ trends at the regional scale listed above, our results among many others highlight the need for acquiring sustained time series of the ocean carbonate system in different regions as was strongly recommended at the recent Ocean-Obs19 conference (Tilbrook et al., 2019; Wanninkhof et al., 2019).

An understanding of these differences also calls for a comprehensive analysis including a synthesis of all DIC and TA sea surface observations collected in different regions. This should be achieved at an international level as is done for sea surface $f \mathrm{CO}_{2}$ in the frame of SOCAT (Bakker et al., 2016) or for CLIVAR GO-SHIP cruises assembled in GLODAP (Olsen et al., 2019). In addition to ship-based observations, the analysis of data from BGC Argo floats equipped with $\mathrm{pH}$ sensors (together with temperature and salinity sensors, from which TA, DIC and $f \mathrm{CO}_{2}$ can be estimated (e.g., Williams et al., 2017) will help to better constrain spatial, seasonal and interannual variability. Such data synthesis would also help to validate ocean and Earth system models that at present do not correctly represent the temporal change in marine biogeochemistry as demonstrated by Lebehot et al. (2019) for the North Atlantic.

Data availability. The dataset is freely available and is accessible at http://www.seanoe.org/data/00434/54517/ (http://doi.org/10.17882/ 54517 (last access: 10 March 2020), Reverdin et al. (2018b).

Supplement. The supplement related to this article is available online at: https://doi.org/10.5194/bg-17-2553-2020-supplement.

Author contributions. CL produced the data analyses and wrote the manuscript with input from NM, GR and CLM. GR, NM and VR produced the data synthesis. SO provided the nutrient data. JF provided the DIC and TA data.

Competing interests. The authors declare that they have no conflict of interest.

Special issue statement. This article is part of the special issue "The 10th International Carbon Dioxide Conference (ICDC10) and the 19th WMO/IAEA Meeting on Carbon Dioxide, other Greenhouse Gases and Related Measurement Techniques (GGMT-2017) (AMT/ACP/BG/CP/ESD inter-journal SI)". It is a result of the 10th International Carbon Dioxide Conference, Interlaken, Switzerland, 21-25 August 2017.

Acknowledgements. The SURATLANT project is supported by the French institute INSU (Institut National des Sciences de l'Univers), the Lamont-Doherty Earth Observatory (LDEO), the National Oceanic and Atmospheric Administration (NOAA) - Atlantic Oceanographic and Meteorological Laboratory (AOML) and the Climate Program Office (CPO). We thank the EIMSKIP Company and the MFRI team, both based in Reykjavík (Iceland), for their cooperation in seawater sampling and analysis. We also thank the numerous scientific volunteers who worked at sea as well as 
the crew and captain of the vessels for their help. Support from the European Integrated Projects CARBOOCEAN (511176) and CARBOCHANGE (264879) is also acknowledged. We thank the reviewers Are Olsen and the anonymous reviewer for their helpful comments on this work. We would like to pay tribute to our late colleague Taro Takahashi, who contributed to initiate this sampling in 1993 and was a strong source of motivation for maintaining this long-time monitoring.

Financial support. This research has been supported by the European Integrated Projects CARBOOCEAN (511176) and CARBOCHANGE (264879).

Review statement. This paper was edited by Christoph Heinze and reviewed by Are Olsen and one anonymous referee.

\section{References}

Bakker, D. C. E., Pfeil, B., Landa, C. S., Metzl, N., O’Brien, K. M., Olsen, A., Smith, K., Cosca, C., Harasawa, S., Jones, S. D., Nakaoka, S., Nojiri, Y., Schuster, U., Steinhoff, T., Sweeney, C., Takahashi, T., Tilbrook, B., Wada, C., Wanninkhof, R., Alin, S. R., Balestrini, C. F., Barbero, L., Bates, N. R., Bianchi, A. A., Bonou, F., Boutin, J., Bozec, Y., Burger, E. F., Cai, W.-J., Castle, R. D., Chen, L., Chierici, M., Currie, K., Evans, W., Featherstone, C., Feely, R. A., Fransson, A., Goyet, C., Greenwood, N., Gregor, L., Hankin, S., Hardman-Mountford, N. J., Harlay, J., Hauck, J., Hoppema, M., Humphreys, M. P., Hunt, C. W., Huss, B., Ibánhez, J. S. P., Johannessen, T., Keeling, R., Kitidis, V., Körtzinger, A., Kozyr, A., Krasakopoulou, E., Kuwata, A., Landschützer, P., Lauvset, S. K., Lefèvre, N., Lo Monaco, C., Manke, A., Mathis, J. T., Merlivat, L., Millero, F. J., Monteiro, P. M. S., Munro, D. R., Murata, A., Newberger, T., Omar, A. M., Ono, T., Paterson, K., Pearce, D., Pierrot, D., Robbins, L. L., Saito, S., Salisbury, J., Schlitzer, R., Schneider, B., Schweitzer, R., Sieger, R., Skjelvan, I., Sullivan, K. F., Sutherland, S. C., Sutton, A. J., Tadokoro, K., Telszewski, M., Tuma, M., van Heuven, S. M. A. C., Vandemark, D., Ward, B., Watson, A. J., and Xu, S.: A multidecade record of high-quality $f \mathrm{CO}_{2}$ data in version 3 of the Surface Ocean $\mathrm{CO}_{2}$ Atlas (SOCAT), Earth Syst. Sci. Data, 8, 383413, https://doi.org/10.5194/essd-8-383-2016, 2016.

Bates, N., Astor, Y., Church, M., Currie, K., Dore, J., GonaálezDávila, M., Lorenzoni, L., Muller-Karger, F., Olafsson, J. and Santa-Casiano, M.: A Time-Series View of Changing Ocean Chemistry Due to Ocean Uptake of Anthropogenic $\mathrm{CO}_{2}$ and Ocean Acidification, Oceanography, 27, 126-141, https://doi.org/10.5670/oceanog.2014.16, 2014.

Beaugrand, G., McQuatters-Gollop, A., Edwards, M., and Goberville, E.: Long-term responses of North Atlantic calcifying plankton to climate change, Nat. Clim. Change, 3, 263-267, https://doi.org/10.1038/nclimate1753, 2013.

Becker, M., Steinhoff, T., and Körtzinger, A.: A Detailed View on the Seasonality of Stable Carbon Isotopes Across the North Atlantic, Global Biogeochem. Cy., 32, 1406-1419, https://doi.org/10.1029/2018GB005905, 2018.
Breeden, M. L. and McKinley, G. A.: Climate impacts on multidecadal $p \mathrm{CO}_{2}$ variability in the North Atlantic: 1948-2009, Biogeosciences, 13, 3387-3396, https://doi.org/10.5194/bg-133387-2016, 2016.

Brown, C. W. and Yoder, J. A.: Distribution pattern of coccolithophorid blooms in the western North Atlantic Ocean, Cont. Shelf Res., 14, 175-197, https://doi.org/10.1016/02784343(94)90012-4, 1994.

Chafik, L., Rossby, T., and Schrum, C.: On the spatial structure and temporal variability of poleward transport between Scotland and Greenland, J. Geophys. Res.-Oceans, 119, 824-841, https://doi.org/10.1002/2013JC009287, 2014.

Chafik, L., Nilsen, J. E. Ø., Dangendorf, S., Reverdin, G., and Frederikse, T.: North Atlantic Ocean Circulation and Decadal Sea Level Change During the Altimetry Era, Sci. Rep., 9, 1-9, https://doi.org/10.1038/s41598-018-37603-6, 2019.

Clement, D. and Gruber, N.: The eMLR(C*) Method to Determine Decadal Changes in the Global Ocean Storage of Anthropogenic $\mathrm{CO}_{2}$, Global Biogeochem. Cy., 32, 654-679, https://doi.org/10.1002/2017GB005819, 2018.

Corbière, A., Metzl, N., Reverdin, G., Brunet, C., and Takahashi, T.: Interannual and decadal variability of the oceanic carbon sink in the North Atlantic subpolar gyre, Tellus B, 59, 168-178, https://doi.org/10.1111/j.1600-0889.2006.00232.x, 2007.

De Boisséson, E., Thierry, V., Mercier, H., Caniaux, G., and Desbruyères, D.: Origin, formation and variability of the Subpolar Mode Water located over the Reykjanes Ridge, J. Geophys. Res.Oceans, 117, C12005, https://doi.org/10.1029/2011JC007519, 2012.

Denvil-Sommer, A., Gehlen, M., Vrac, M., and Mejia, C.: LSCEFFNN-v1: a two-step neural network model for the reconstruction of surface ocean $p \mathrm{CO}_{2}$ over the global ocean, Geosci. Model Dev., 12, 2091-2105, https://doi.org/10.5194/gmd-122091-2019, 2019.

Desbruyères, D., Mercier, H., and Thierry, V.: On the mechanisms behind decadal heat content changes in the eastern subpolar gyre, Prog. Oceanogr., 132, 262-272, https://doi.org/10.1016/j.pocean.2014.02.005, 2015.

Dickson, A. G.: Standard potential of the reaction: $\mathrm{AgCl}(\mathrm{s})+12 \mathrm{H} 2(\mathrm{~g})=\mathrm{Ag}(\mathrm{s})+\mathrm{HCl}(\mathrm{aq}), \quad$ and the standard acidity constant of the ion $\mathrm{HSO}_{4}$ - in synthetic sea water from 273.15 to $318.15 \mathrm{~K}$, J. Chem. Thermodyn., 22, 113-127, https://doi.org/10.1016/0021-9614(90)90074-Z, 1990.

Dickson, A. G. and Millero, F. J.: A comparison of the equilibrium constants for the dissociation of carbonic acid in seawater media, Deep-Sea Res. Pt. I, 34, 1733-1743, https://doi.org/10.1016/0198-0149(87)90021-5, 1987.

Dlugokencky, E. J., Lang, P. M., Mund, J. W., Crotwell, M. J., and Thoning, K. W.: Atmospheric Carbon Dioxide Dry Air Mole Fractions from the NOAA ESRL Carbon Cycle Cooperative Global Air Sampling Network, 1968-2017, Version: 2018-0731, available at: https://www.esrl.noaa.gov/gmd/dv/iadv/, last access: 6 March 2019.

Doney, S., Bopp, L., and Long, M.: Historical and Future Trends in Ocean Climate and Biogeochemistry, Oceanog, 27, 108-119, https://doi.org/10.5670/oceanog.2014.14, 2014.

Doney, S. C., Fabry, V. J., Feely, R. A., and Kleypas, J. A.: Ocean Acidification: The Other $\mathrm{CO}_{2}$ 
Problem, Ann. Rev. Mar. Sci., 1, 169-192, https://doi.org/10.1146/annurev.marine.010908.163834, 2009.

Fay, A. R. and McKinley, G. A.: Global trends in surface ocean $p \mathrm{CO}_{2}$ from in situ data, Global Biogeochem. Cy., 27, 541-557, https://doi.org/10.1002/gbc.20051, 2013.

Fay, A. R. and McKinley, G. A.: Global open-ocean biomes: mean and temporal variability, Earth Syst. Sci. Data, 6, 273-284, https://doi.org/10.5194/essd-6-273-2014, 2014.

Friedlingstein, P., Jones, M. W., O’Sullivan, M., Andrew, R. M., Hauck, J., Peters, G. P., Peters, W., Pongratz, J., Sitch, S., Le Quéré, C., Bakker, D. C. E., Canadell, J. G., Ciais, P., Jackson, R. B., Anthoni, P., Barbero, L., Bastos, A., Bastrikov, V., Becker, M., Bopp, L., Buitenhuis, E., Chandra, N., Chevallier, F., Chini, L. P., Currie, K. I., Feely, R. A., Gehlen, M., Gilfillan, D., Gkritzalis, T., Goll, D. S., Gruber, N., Gutekunst, S., Harris, I., Haverd, V., Houghton, R. A., Hurtt, G., Ilyina, T., Jain, A. K., Joetzjer, E., Kaplan, J. O., Kato, E., Klein Goldewijk, K., Korsbakken, J. I., Landschützer, P., Lauvset, S. K., Lefèvre, N., Lenton, A., Lienert, S., Lombardozzi, D., Marland, G., McGuire, P. C., Melton, J. R., Metzl, N., Munro, D. R., Nabel, J. E. M. S., Nakaoka, S.-I., Neill, C., Omar, A. M., Ono, T., Peregon, A., Pierrot, D., Poulter, B., Rehder, G., Resplandy, L., Robertson, E., Rödenbeck, C., Séférian, R., Schwinger, J., Smith, N., Tans, P. P., Tian, H., Tilbrook, B., Tubiello, F. N., van der Werf, G. R., Wiltshire, A. J., and Zaehle, S.: Global Carbon Budget 2019, Earth Syst. Sci. Data, 11, 1783-1838, https://doi.org/10.5194/essd-111783-2019, 2019.

Friis, K., Körtzinger, A., and Wallace, D. W. R.: The salinity normalization of marine inorganic carbon chemistry data, Geophys. Res. Lett., 30, 1085, https://doi.org/10.1029/2002GL015898, 2003.

Fröb, F., Olsen, A., Våge, K., Moore, G. W. K., Yashayaev, I., Jeansson, E., and Rajasakaren, B.: Irminger Sea deep convection injects oxygen and anthropogenic carbon to the ocean interior, Nat. Commun., 7, 1-8, https://doi.org/10.1038/ncomms13244, 2016.

Fröb, F., Olsen, A., Pérez, F. F., García-Ibáñez, M. I., Jeansson, E., Omar, A., and Lauvset, S. K.: Inorganic carbon and water masses in the Irminger Sea since 1991, Biogeosciences, 15, 5172, https://doi.org/10.5194/bg-15-51-2018, 2018.

Fröb, F., Olsen, A., Becker, M., Chafik, L., Johannessen, T., Reverdin, G. and Omar, A.: Wintertime $f \mathrm{CO}_{2}$ Variability in the Subpolar North Atlantic Since 2004, Geophys. Res. Lett., 46, 1580-1590, https://doi.org/10.1029/2018GL080554, 2019.

García-Ibáñez, M. I., Zunino, P., Fröb, F., Carracedo, L. I., Ríos, A. F., Mercier, H., Olsen, A., and Pérez, F. F.: Ocean acidification in the subpolar North Atlantic: rates and mechanisms controlling $\mathrm{pH}$ changes, Biogeosciences, 13, 3701-3715, https://doi.org/10.5194/bg-13-3701-2016, 2016.

Goris, N., Tjiputra, J. F., Olsen, A., Schwinger, J., Lauvset, S. K. and Jeansson, E.: Constraining projection-based estimates of the future North Atlantic carbon uptake, J. Climate, 31, 3959-3978, https://doi.org/10.1175/JCLI-D-17-0564.1,2018.

Gregor, L., Lebehot, A. D., Kok, S., and Scheel Monteiro, P. M.: A comparative assessment of the uncertainties of global surface ocean $\mathrm{CO}_{2}$ estimates using a machine-learning ensemble (CSIR-ML6 version 2019a) - have we hit the wall?, Geosci. Model Dev., 12, 5113-5136, https://doi.org/10.5194/gmd-125113-2019, 2019.
Gruber, N., Clement, D., Carter, B. R., Feely, R. A., Heuven, S. van, Hoppema, M., Ishii, M., Key, R. M., Kozyr, A., Lauvset, S. K., Lo Monaco, C., Mathis, J. T., Murata, A., Olsen, A., Perez, F. F., Sabine, C. L., Tanhua, T. and Wanninkhof, R.: The oceanic sink for anthropogenic $\mathrm{CO}_{2}$ from 1994 to 2007, Science, 363, 1193-1199, https://doi.org/10.1126/science.aau5153, 2019a.

Gruber, N., Clement, D., Carter, B. R., Feely, R. A., Heuven, S. van, Hoppema, M., Ishii, M., Key, R. M., Kozyr, A., Lauvset, S. K., Lo Monaco, C., Mathis, J. T., Murata, A., Olsen, A., Perez, F. F., Sabine, C. L., Tanhua, T., and Wanninkhof, R.: The oceanic sink for anthropogenic $\mathrm{CO}_{2}$ from 1994 to 2007 - the data (NCEI Accession 0186034), NOAA National Centers for Environmental Information. Dataset, https://doi.org/10.25921/wdn2pt10, 2019b.

Häkkinen, S. and Rhines, P. B.: Decline of Subpolar North Atlantic Circulation During the 1990s, Science, 304, 555-559, https://doi.org/10.1126/science.1094917, 2004.

Häkkinen, S. and Rhines, P. B.: Shifting surface currents in the northern North Atlantic Ocean, J. Geophys. Res.-Oceans, 114, C04005, https://doi.org/10.1029/2008JC004883, 2009.

Häkkinen, S., Rhines, P. B., and Worthen, D. L.: Atmospheric Blocking and Atlantic Multidecadal Ocean Variability, Science, 334, 655-659, https://doi.org/10.1126/science.1205683, 2011.

Häkkinen, S., Rhines, P. B., and Worthen, D. L.: Northern North Atlantic sea surface height and ocean heat content variability, J. Geophys. Res.-Oceans, 118, 3670-3678, https://doi.org/10.1002/jgrc.20268, 2013.

Hartmann, D. L., Klein Tank, A. M. G., Rusticucci, M., Alexander, L. V., Brönnimann, S., Charabi, Y., Dentener, F. J., Dlugokencky, E. J., Easterling, D. R., Kaplan, A., Soden, B. J., Thorne, P. W., Wild, M., and Zhai, P. M.: Observations: Atmosphere and Surface. In: Climate Change 2013: The Physical Science Basis, Contribution of Working Group I to the Fifth Assessment Report of the Intergovernmental Panel on Climate Change, edited by: Stocker, T. F., Qin, D., Plattner, G.K., Tignor, M., Allen, S. K., Boschung, J., Nauels, A., Xia, Y., Bex, V., and Midgley, P. M., Cambridge University Press, Cambridge, United Kingdom and New York, NY, USA, 159-254, https://doi.org/10.1017/CBO9781107415324.008, 2013.

Hátún, H., Azetsu-Scott, K., Somavilla, R., Rey, F., Johnson, C., Mathis, M., Mikolajewicz, U., Coupel, P., Tremblay, J.-É., Hartman, S., Pacariz, S. V., Salter, I., and Ólafsson, J.: The subpolar gyre regulates silicate concentrations in the North Atlantic, Sci. Rep., 7, 1-9, https://doi.org/10.1038/s41598-017-14837-4, 2017.

Henson, S. A., Painter, S. C., Holliday, N. P., Stinchcombe, M. C., and Giering, S. L. C.: Unusual subpolar NorthAtlantic phytoplankton bloom in 2010: Volcanic fertilization or North Atlantic Oscillation?, J. Geophys. Res.-Oceans, 118, 4771-4780, https://doi.org/10.1002/jgrc.20363, 2013.

van Heuven, S., Pierrot, D., Rae, J. W. B., Lewis, E., and Wallace, D. W. R.: MATLAB Program Developed for $\mathrm{CO}_{2}$ System Calculations, ORNL/CDIAC-105b, 2011.

Holliday, N. P., Bersch, M., Berx, B., Chafik, L., Cunningham, S.,Florindo-Lopez, C., Hátún, H., Johns, W., Josey, S., A., Larsen, K., M., H., Mulet, S., Oltmanns, M., Reverdin, G., Rossby, T., Thierry, V., Valdimarsson, H.: Ocean circulation causes the largest freshening event for 120 years in eastern subpolar North Atlantic, Nat. Commun., 11, 585, https://doi.org/10.1038/s41467-020-14474-y, 2020. 
Jiang, L.-Q., Carter, B. R., Feely, R. A., Lauvset, S. K., and Olsen, A.: Surface ocean $\mathrm{pH}$ and buffer capacity: past, present and future, Sci. Rep., 9, 1-11, https://doi.org/10.1038/s41598-01955039-4, 2019.

de Jong, M. F. and de Steur, L.: Strong winter cooling over the Irminger Sea in winter 2014-2015, exceptional deep convection, and the emergence of anomalously low SST, Geophys. Res. Lett., 43, 7106-7113, https://doi.org/10.1002/2016GL069596, 2016.

Josey, S. A., Hirschi, J. J.-M., Sinha, B., Duchez, A., Grist, J. P., and Marsh, R.: The Recent Atlantic Cold Anomaly: Causes, Consequences, and Related Phenomena, Ann. Rev. Mar. Sci., 10, 475-501, https://doi.org/10.1146/annurev-marine121916-063102, 2018.

Keeling, C. D., Brix, H., and Gruber, N.: Seasonal and longterm dynamics of the upper ocean carbon cycle at Station ALOHA near Hawaii, Global Biogeochem. Cy., 18, GB4006, https://doi.org/10.1029/2004GB002227, 2004.

Keller, K., Joos, F., Raible, C., Cocco, V., Frolicher, T., Dunne, J., Gehlen, M., Bopp, L., Orr, J., Tjiputra, J., Heinze, C., Segscheider, J., Roy, T., and Metzl, N.: Variability of the Ocean Carbon Cycle in Response to the North Atlantic Oscillation, Tellus B, 64, 18738, https://doi.org/10.3402/tellusb.v64i0.18738, 2012.

Key, R. M., Olsen, A., van Heuven, S., Lauvset, S. K., Velo, A., Lin, X., Schirnick, C., Kozyr, A., Tanhua, T., Hoppema, M., Jutterström, S., Steinfeldt, R., Jeansson, E., Ishii, M., Perez, F. F., and Suzuki, T.: Global Ocean Data Analysis Project, Version 2 (GLODAPv2), ORNL/CDIAC-162, NDP-093, https://doi.org/10.3334/CDIAC/OTG, NDP093_GLODAPv2, 2015.

Khatiwala, S., Tanhua, T., Mikaloff Fletcher, S., Gerber, M., Doney, S. C., Graven, H. D., Gruber, N., McKinley, G. A., Murata, A., Ríos, A. F., and Sabine, C. L.: Global ocean storage of anthropogenic carbon, Biogeosciences, 10, 2169-2191, https://doi.org/10.5194/bg-10-2169-2013, 2013.

Kwiatkowski, L. and Orr, J. C.: Diverging seasonal extremes for ocean acidification during the twenty-first century, Nat. Clim. Change, 8, 141-145, https://doi.org/10.1038/s41558-017-0054$0,2018$.

Landschützer, P., Gruber, N., Bakker, D. C. E., Schuster, U., Nakaoka, S., Payne, M. R., Sasse, T. P., and Zeng, J.: A neural network-based estimate of the seasonal to inter-annual variability of the Atlantic Ocean carbon sink, Biogeosciences, 10, 7793-7815, https://doi.org/10.5194/bg-10-7793-2013, 2013.

Landschützer, P., Gruber, N., Bakker, D. C. E., Stemmler, I. and Six, K. D.: Strengthening seasonal marine $\mathrm{CO}_{2}$ variations due to increasing atmospheric $\mathrm{CO}_{2}$, Nat. Clim. Change, 8, 146-150, https://doi.org/10.1038/s41558-017-0057-x, 2018.

Landschützer, P., Ilyina, T., and Lovenduski, N. S.: Detecting Regional Modes of Variability in Observation-Based Surface Ocean $p \mathrm{CO}_{2}$, Geophys. Res. Lett., 46, 2670-2679, https://doi.org/10.1029/2018GL081756, 2019.

Lauvset, S. K. and Gruber, N.: Long-term trends in surface ocean $\mathrm{pH}$ in the North Atlantic, 0304-4203, https://doi.org/10.1016/j.marchem.2014.03.009, 2014.

Lauvset, S. K., Gruber, N., Landschützer, P., Olsen, A., and Tjiputra, J.: Trends and drivers in global surface ocean $\mathrm{pH}$ over the past 3 decades, Biogeosciences, 12, 1285-1298, https://doi.org/10.5194/bg-12-1285-2015, 2015.
Le Quéré, C., Andrew, R. M., Friedlingstein, P., Sitch, S., Hauck, J., Pongratz, J., Pickers, P. A., Korsbakken, J. I., Peters, G. P., Canadell, J. G., Arneth, A., Arora, V. K., Barbero, L., Bastos, A., Bopp, L., Chevallier, F., Chini, L. P., Ciais, P., Doney, S. C., Gkritzalis, T., Goll, D. S., Harris, I., Haverd, V., Hoffman, F. M., Hoppema, M., Houghton, R. A., Hurtt, G., Ilyina, T., Jain, A. K., Johannessen, T., Jones, C. D., Kato, E., Keeling, R. F., Goldewijk, K. K., Landschützer, P., Lefèvre, N., Lienert, S., Liu, Z., Lombardozzi, D., Metzl, N., Munro, D. R., Nabel, J. E. M. S., Nakaoka, S., Neill, C., Olsen, A., Ono, T., Patra, P., Peregon, A., Peters, W., Peylin, P., Pfeil, B., Pierrot, D., Poulter, B., Rehder, G., Resplandy, L., Robertson, E., Rocher, M., Rödenbeck, C., Schuster, U., Schwinger, J., Séférian, R., Skjelvan, I., Steinhoff, T., Sutton, A., Tans, P. P., Tian, H., Tilbrook, B., Tubiello, F. N., van der Laan-Luijkx, I. T., van der Werf, G. R., Viovy, N., Walker, A. P., Wiltshire, A. J., Wright, R., Zaehle, S., and Zheng, B.: Global Carbon Budget 2018, Earth Syst. Sci. Data, 10, 21412194, https://doi.org/10.5194/essd-10-2141-2018, 2018.

Lebehot, A. D., Halloran, P. R., Watson, A. J., McNeall, D., Ford, D. A., Landschützer, P., Lauvset, S. K., and Schuster, U.: Reconciling Observation and Model Trends in North Atlantic Surface $\mathrm{CO}_{2}$, Global Biogeochem. Cy., 33, 1204-1222, https://doi.org/10.1029/2019GB006186, 2019.

Lee, K., Tong, L. T., Millero, F. J., Sabine, C. L., Dickson, A. G., Goyet, C., Park, G.-H., Wanninkhof, R., Feely, R. A., and Key, R. M.: Global relationships of total alkalinity with salinity and temperature in surface waters of the world's oceans, Geophys. Res. Lett., 33, L19605, https://doi.org/10.1029/2006GL027207, 2006.

Lewis, E., Wallace, D., and Allison, L. J.: Program developed for $\mathrm{CO}_{2}$ system calculations, Brookhaven National Lab., Dept. of Applied Science, Upton, NY (United States); Oak Ridge National Lab., Carbon Dioxide Information Analysis Center, TN (United States), 1998.

Loveday, B. R. and Smyth, T.: A 40-year global data set of visiblechannel remote-sensing reflectances and coccolithophore bloom occurrence derived from the Advanced Very High Resolution Radiometer catalogue, Earth Syst. Sci. Data, 10, 2043-2054, https://doi.org/10.5194/essd-10-2043-2018, 2018.

Macovei, V. A., Hartman, S. E., Schuster, U., Torres-Valdés, S., Moore, C. M., and Sanders, R. J.: Impact of physical and biological processes on temporal variations of the ocean carbon sink in the mid-latitude North Atlantic (2002-2016), Prog. Oceanogr., 180, 102223, https://doi.org/10.1016/j.pocean.2019.102223, 2019.

Martinez, E., Raitsos, D. E., and Antoine, D.: Warmer, deeper, and greener mixed layers in the North Atlantic subpolar gyre over the last 50 years, Glob. Chang. Biol. 22, 604-612, https://doi.org/10.1111/gcb.13100, 2016.

McKinley, G. A., Fay, A. R., Takahashi, T., and Metzl, N.: Convergence of atmospheric and North Atlantic carbon dioxide trends on multidecadal timescales, Nat. Geosci., 4, 606-610, https://doi.org/10.1038/ngeo1193, 2011.

McKinley, G. A., Ritzer, A. L., and Lovenduski, N. S.: Mechanisms of northern North Atlantic biomass variability, Biogeosciences, 15, 6049-6066, https://doi.org/10.5194/bg-15-6049-2018, 2018.

Mehrbach, C., Culberson, C. H., Hawley, J. E., and Pytkowicx, R. M.: Measurement of the Apparent Dissociation Constants of Carbonic Acid in Seawater at At- 
mospheric Pressure1, Limnol. Oceanogr., 18, 897-907, https://doi.org/10.4319/lo.1973.18.6.0897, 1973.

Metzl, N., Corbière, A., Reverdin, G., Lenton, A., Takahashi, T., Olsen, A., Johannessen, T., Pierrot, D., Wanninkhof, R., Ólafsdóttir, S. R., Olafsson, J., and Ramonet, M.: Recent acceleration of the sea surface $f \mathrm{CO}_{2}$ growth rate in the North Atlantic subpolar gyre (1993-2008) revealed by winter observations, Global Biogeochem. Cy., 24, GB4004, https://doi.org/10.1029/2009GB003658, 2010.

Metzl, N., Ferron, B., Lherminier, P., Sarthou, G., and Thierry, V.: Discrete profile measurements of dissolved inorganic carbon (DIC), total alkalinity (TALK), temperature and salinity during the multiple ships Observatoire de la variabilité interannuelle et décennale en Atlantique Nord (OVIDE) project, OVIDE-2006, OVIDE-2008, OVIDE-2010, OVIDE2012, OVIDE-2014 cruises in the North Atlantic Ocean from 2006-05-23 to 2014-06-30 (NCEI Accession 0177219), Version 1.1, NOAA National Centers for Environmental Information, Dataset, https://doi.org/10.25921/v0qt-ms48, 2018.

Millero, F. J., Lee, K., and Roche, M.: Distribution of alkalinity in the surface waters of the major oceans, Mar. Chem., 60, 111-130, https://doi.org/10.1016/S0304-4203(97)00084-4, 1998.

Millero, F. J., Feistel, R., Wright, D. G., and McDougall, T. J.: The composition of standar seawater and the definition of the reference-composition salinity scale, Deep-Sea Res. Pt. I, 55, 50-72, https://doi.org/10.1016/j.dsr.2007.10.001, 2008.

Munro, D. R., Lovenduski, N. S., Takahashi, T., Stephens, B. B., Newberger, T., and Sweeney C.: Recent evidence for a strengthening $\mathrm{CO}_{2}$ sink in the Southern Ocean from carbonate system measurements in the Drake Passage (2002-2015), Geophys. Res. Lett., 42, 7623-7630, https://doi.org/10.1002/2015GL065194, 2015.

Nigam, S., Ruiz-Barradas, A., and Chafik, L.: Gulf Stream Excursions and Sectional Detachments Generate the Decadal Pulses in the Atlantic Multidecadal Oscillation, J. Climate, 31, 2853-2870, https://doi.org/10.1175/JCLI-D-17-0010.1, 2018.

Olafsson, J., Olafsdottir, S. R., Benoit-Cattin, A., Danielsen, M., and Takahashi, T.: North Atlantic Ocean acidification from time series measurements, IOP Conf. Ser.: Earth Environ. Sci., 6, 462005, https://doi.org/10.1088/1755-1307/6/46/462005, 2009.

Olafsson, J., Olafsdottir, S. R., Benoit-Cattin, A., and Takahashi, T.: The Irminger Sea and the Iceland Sea time series measurements of sea water carbon and nutrient chemistry 1983-2008, Earth Syst. Sci. Data, 2, 99-104, https://doi.org/10.5194/essd-299-2010, 2010.

Olsen, A., Key, R. M., van Heuven, S., Lauvset, S. K., Velo, A., Lin, X., Schirnick, C., Kozyr, A., Tanhua, T., Hoppema, M., Jutterström, S., Steinfeldt, R., Jeansson, E., Ishii, M., Pérez, F. F., and Suzuki, T.: The Global Ocean Data Analysis Project version 2 (GLODAPv2) - an internally consistent data product for the world ocean, Earth Syst. Sci. Data, 8, 297-323, https://doi.org/10.5194/essd-8-297-2016, 2016.

Olsen, A., Lange, N., Key, R. M., Tanhua, T., Álvarez, M., Becker, S., Bittig, H. C., Carter, B. R., Cotrim da Cunha, L., Feely, R. A., van Heuven, S., Hoppema, M., Ishii, M., Jeansson, E., Jones, S. D., Jutterström, S., Karlsen, M. K., Kozyr, A., Lauvset, S. K., Lo Monaco, C., Murata, A., Pérez, F. F., Pfeil, B., Schirnick, C., Steinfeldt, R., Suzuki, T., Telszewski, M., Tilbrook, B., Velo, A., and Wanninkhof, R.: GLODAPv2.2019- an update of GLODAPv2, Earth Syst. Sci. Data, 11, 1437-1461, https://doi.org/10.5194/essd-11-1437-2019, 2019.

Omar, A. M., Thomas, H., Olsen, A., Becker, M., Skjelvan, I., and Reverdin, G.: Trends of Ocean Acidification and $p \mathrm{CO}_{2}$ in the Northern North Sea, 2003-2015, J. Geophys. Res.-Biogeo., 124, 3088-3103, https://doi.org/10.1029/2018JG004992, 2019.

Ono, H., Kosugi, N., Toyama, K., Tsujino, H., Kojima, A., Enyo, K., Iida, Y., Nakano, T., and Ishii, M.: Acceleration of Ocean Acidification in the Western North Pacific, Geophys. Res. Lett., 46, 13161-13169, https://doi.org/10.1029/2019GL085121, 2019.

Organization (WMO), W. M., (UNESCO) United Nations Educational, S. and C. O., Commission, (IOC) Intergovernmental Oceanographic, Programme, (UNEP) United Nations Environment, Science, (ICSU) International Council for, Climate (OOPC-21), 21st Session of the Ocean Observations Panel for and World Meteorological Organization (WMO): GCOS, 217, 21st Session of the Ocean Observations Panel for Climate (the GOOS Physics and Climate Panel) (OOPC-21), WMO, 2018.

Orr, J. C., Fabry, V. J., Aumont, O., Bopp, L., Doney, S. C., Feely, R. A., Gnanadesikan, A., Gruber, N., Ishida, A., Joos, F., Key, R. M., Lindsay, K., Maier-Reimer, E., Matear, R., Monfray, P., Mouchet, A., Najjar, R. G., Plattner, G.-K., Rodgers, K. B., Sabine, C. L., Sarmiento, J. L., Schlitzer, R., Slater, R. D., Totterdell, I. J., Weirig, M.-F., Yamanaka, Y., and Yool, A.: Anthropogenic ocean acidification over the twenty-first century and its impact on calcifying organisms, Nature, 437, 681-686, https://doi.org/10.1038/nature04095, 2005.

Orr, J. C., Epitalon, J.-M., Dickson, A. G., and Gattuso, J.-P.: Routine uncertainty propagation for the marine carbon dioxide system, Mar. Chem., 207, 84-107, https://doi.org/10.1016/j.marchem.2018.10.006, 2018.

Pickart, R. S., Spall, M. A., Ribergaard, M. H., Moore, G. W. K., and Milliff, R. F.: Deep convection in the Irminger Sea forced by the Greenland tip jet, Nature, 424, 152-156, https://doi.org/10.1038/nature01729, 2003.

Piron, A., Thierry, V., Mercier, H., and Caniaux, G.: Gyre-scale deep convection in the subpolar North Atlantic Ocean during winter 2014-2015, Geophys. Res. Lett., 44, 1439-1447, https://doi.org/10.1002/2016GL071895, 2017.

Racapé, V., Pierre, C., Metzl, N., Lo Monaco, C., Reverdin, G., Olsen, A., Morin, P., Vázquez-Rodríguez, M., Ríos, A. F., and Pérez, F. F.: Anthropogenic carbon changes in the Irminger Basin (1981-2006): Coupling $\delta 13$ CDIC and DIC observations, J. Mar. Syst., 126, 24-32, https://doi.org/10.1016/j.jmarsys.2012.12.005, 2013.

Racapé, V., Metzl, N., Pierre, C., Reverdin, G., Quay, P. D., and Olafsdottir, S. R.: The seasonal cycle of $\delta^{3} \mathrm{C}_{\mathrm{DIC}}$ in the North Atlantic subpolar gyre, Biogeosciences, 11, 1683-1692, https://doi.org/10.5194/bg-11-1683-2014, 2014.

Reverdin, G., Valdimarsson, H., Alory, G., Diverres, D., Bringas, F., Goni, G., Heilmann, L., Chafik, L., Szekely, T., and Friedman, A. R.: North Atlantic subpolar gyre along predetermined ship tracks since 1993: a monthly data set of surface temperature, salinity, and density, Earth Syst. Sci. Data, 10, 1403-1415, https://doi.org/10.5194/essd-10-1403-2018, 2018a.

Reverdin, G., Metzl, N., Olafsdottir, S., Racapé, V., Takahashi, T., Benetti, M., Valdimarsson, H., Benoit-Cattin, A., Danielsen, M., Fin, J., Naamar, A., Pierrot, D., Sullivan, K., Bringas, F., and Goni, G.: SURATLANT: a 1993-2017 surface sampling in the 
central part of the North Atlantic subpolar gyre, Earth Syst. Sci. Data, 10, 1901-1924, https://doi.org/10.5194/essd-10-19012018, 2018b.

Rivero-Calle, S., Gnanadesikan, A., Del Castillo, C. E., Balch, W. M., and Guikema, S. D.: Multidecadal increase in North Atlantic coccolithophores and the potential role of rising $\mathrm{CO}_{2}$, Science, 350, 1533-1537, https://doi.org/10.1126/science.aaa8026, 2015.

Robson, J., Ortega, P., and Sutton, R.: A reversal of climatic trends in the North Atlantic since 2005, Nat. Geosci., 9, 513-517, https://doi.org/10.1038/ngeo2727, 2016.

Robson, J., Polo, I., Hodson, D. L. R., Stevens, D. P., and Shaffrey, L. C.: Decadal prediction of the North Atlantic subpolar gyre in the HiGEM high-resolution climate model, Clim. Dynam., 50, 921-937, https://doi.org/10.1007/s00382-017-3649-2, 2018.

Rödenbeck, C., Bakker, D. C. E., Gruber, N., Iida, Y., Jacobson, A. R., Jones, S., Landschützer, P., Metzl, N., Nakaoka, S., Olsen, A., Park, G.-H., Peylin, P., Rodgers, K. B., Sasse, T. P., Schuster, U., Shutler, J. D., Valsala, V., Wanninkhof, R., and Zeng, J.: Data-based estimates of the ocean carbon sink variability - first results of the Surface Ocean $p \mathrm{CO}_{2}$ Mapping intercomparison (SOCOM), Biogeosciences, 12, 72517278, https://doi.org/10.5194/bg-12-7251-2015, 2015.

Sabine, C. L., Feely, R. A., Gruber, N., Key, R. M., Lee, K., Bullister, J. L., Wanninkhof, R., Wong, C. S., Wallace, D. W. R., Tilbrook, B., Millero, F. J., Peng, T.-H., Kozyr, A., Ono, T. and Rios, A. F.: The Oceanic Sink for Anthropogenic $\mathrm{CO}_{2}$, Science, 305, 367-371, https://doi.org/10.1126/science.1097403, 2004.

Schuster, U., Watson, A. J., Bates, N. R., Corbiere, A., Gonzalez-Davila, M., Metzl, N., Pierrot, D., and SantanaCasiano, M.: Trends in North Atlantic sea-surface $f \mathrm{CO}_{2}$ from 1990 to 2006, Deep-Sea Res. Pt. II, 56, 620-629, https://doi.org/10.1016/j.dsr2.2008.12.011, 2009.

Schuster, U., McKinley, G. A., Bates, N., Chevallier, F., Doney, S. C., Fay, A. R., González-Dávila, M., Gruber, N., Jones, S., Krijnen, J., Landschützer, P., Lefèvre, N., Manizza, M., Mathis, J., Metzl, N., Olsen, A., Rios, A. F., Rödenbeck, C., Santana-Casiano, J. M., Takahashi, T., Wanninkhof, R., and Watson, A. J.: An assessment of the Atlantic and Arctic sea-air $\mathrm{CO}_{2}$ fluxes, 1990-2009, Biogeosciences, 10, 607-627, https://doi.org/10.5194/bg-10-607-2013, 2013.

Signorini, S. R., Häkkinen, S., Gudmundsson, K., Olsen, A., Omar, A. M., Olafsson, J., Reverdin, G., Henson, S. A., McClain, C. R., and Worthen, D. L.: The role of phytoplankton dynamics in the seasonal and interannual variability of carbon in the subpolar North Atlantic - a modeling study, Geosci. Model Dev., 5, 683707, https://doi.org/10.5194/gmd-5-683-2012, 2012.

Takahashi, T., Sutherland, S. C., Wanninkhof, R., Sweeney, C., Feely, R. A., Chipman, D. W., Hales, B., Friederich, G., Chavez, F., Sabine, C., Watson, A., Bakker, D. C. E., Schuster, U., Metzl, N., Yoshikawa-Inoue, H., Ishii, M., Midorikawa, T., Nojiri, Y., Körtzinger, A., Steinhoff, T., Hoppema, M., Olafsson, J., Arnarson, T. S., Tilbrook, B., Johannessen, T., Olsen, A., Bellerby, R., Wong, C. S., Delille, B., Bates, N. R., and de Baar, H. J. W.: Climatological mean and decadal change in surface ocean $p \mathrm{CO}_{2}$, and net sea-air $\mathrm{CO}_{2}$ flux over the global oceans, Deep-Sea Res. Pt. II, 56, 554-577, https://doi.org/10.1016/j.dsr2.2008.12.009, 2009.

Takahashi, T., Sutherland, S. C., Chipman, D. W., Goddard, J. G., Ho, C., Newberger, T., Sweeney, C., and Munro, D. R.: Cli- matological distributions of $\mathrm{pH}, p \mathrm{CO}_{2}$, total $\mathrm{CO}_{2}$, alkalinity, and $\mathrm{CaCO}_{3}$ saturation in the global surface ocean, and temporal changes at selected locations, Mar. Chem., 164, 95-125, https://doi.org/10.1016/j.marchem.2014.06.004, 2014.

Thomas, H., Prowe, A. E. F., Lima, I. D., Doney, S. C., Wanninkhof, R., Greatbatch, R. J., Schuster, U., and Corbière, A.: Changes in the North Atlantic Oscillation influence $\mathrm{CO}_{2}$ uptake in the North Atlantic over the past 2 decades, Global Biogeochem. Cy., 22, GB4027, https://doi.org/10.1029/2007GB003167, 2008.

Tilbrook, B., Jewett, E. B., DeGrandpre, M. D., Hernandez-Ayon, J. M., Feely, R. A., Gledhill, D. K., Hansson, L., Isensee, K., Kurz, M. L., Newton, J. A., Siedlecki, S. A., Chai, F., Dupont, S., Graco, M., Calvo, E., Greeley, D., Kapsenberg, L., Lebrec, M., Pelejero, C., Schoo, K. L., and Telszewski, M.: An Enhanced Ocean Acidification Observing Network: From People to Technology to Data Synthesis and Information Exchange, Front. Mar Sci., 6, 337, https://doi.org/10.3389/fmars.2019.00337, 2019.

Tilstone, G. H., Miller, P. I., Brewin, R. J. W., and Priede, I. G.: Enhancement of primary production in the North Atlantic outside of the spring bloom, identified by remote sensing of ocean colour and temperature, Remote Sens. Environ., 146, 77-86, https://doi.org/10.1016/j.rse.2013.04.021, 2014.

Tjiputra, J. F., Olsen, A., Assmann, K., Pfeil, B., and Heinze, C.: A model study of the seasonal and long-term North Atlantic surface $p \mathrm{CO}_{2}$ variability, Biogeosciences, 9, 907-923, https://doi.org/10.5194/bg-9-907-2012, 2012.

Tjiputra, J. F., Olsen, A., Bopp, L., Lenton, A., Pfeil, B., Roy, T., Segschneider, J., Totterdell, I., and Heinze, C.: Long-term surface $p \mathrm{CO}_{2}$ trends from observations and models, Tellus B, 66, 23083, https://doi.org/10.3402/tellusb.v66.23083, 2014.

Touratier, F., Azouzi, L., and Goyet, C.: CFC-11, $\Delta 14 \mathrm{C}$ and $3 \mathrm{H}$ tracers as a means to assess anthropogenic $\mathrm{CO}_{2}$ concentrations in the ocean, Tellus B, 59, 318-325, https://doi.org/10.1111/j.16000889.2006.00247.x, 2007.

Ullman, D. J., McKinley, G. A., Bennington, V., and Dutkiewicz, S.: Trends in the North Atlantic carbon sink: 1992-2006, Global Biogeochem. Cy., 23, GB4011, https://doi.org/10.1029/2008GB003383, 2009.

Uppström, L. R.: The boron/chlorinity ratio of deep-sea water from the Pacific Ocean, Deep Sea Research and Oceanographic Abstracts, 21, 161-162, https://doi.org/10.1016/00117471(74)90074-6, 1974.

Våge, K., Pickart, R. S., Moore, G. W. K., and Ribergaard, M. H.: Winter Mixed Layer Development in the Central Irminger Sea: The Effect of Strong, Intermittent Wind Events, J. Phys. Oceanogr., 38, 541-565, https://doi.org/10.1175/2007JPO3678.1, 2008.

Vázquez-Rodríguez, M., Pérez, F. F., Velo, A., Ríos, A. F., and Mercier, H.: Observed acidification trends in North Atlantic water masses, Biogeosciences, 9, 5217-5230, https://doi.org/10.5194/bg-9-5217-2012, 2012.

Wakita, M., Watanabe, S., Honda, M., Nagano, A., Kimoto, K., Matsumoto, K., Kitamura, M., Sasaki, K., Kawakami, H., Fujiki, T., Sasaoka, K., Nakano, Y., and Murata, A.: Ocean acidification from 1997 to 2011 in the subarctic western North Pacific Ocean, Biogeosciences, 10, 7817-7827, https://doi.org/10.5194/bg-107817-2013, 2013.

Wakita, M., Nagano, A., Fujiki, T., and Watanabe, S.: Slow acidification of the winter mixed layer in the subarctic west- 
ern North Pacific, J. Geophys. Res.-Oceans, 122, 6923-6935, https://doi.org/10.1002/2017JC013002, 2017.

Wanninkhof, R., Pickers, P. A., Omar, A. M., Sutton, A., Murata, A., Olsen, A., Stephens, B. B., Tilbrook, B., Munro, D., Pierrot, D., Rehder, G., Santana-Casiano, J. M., Müller, J. D., Trinanes, J., Tedesco, K., O’Brien, K., Currie, K., Barbero, L., Telszewski, M., Hoppema, M., Ishii, M., González-Dávila, M., Bates, N. R., Metzl, N., Suntharalingam, P., Feely, R. A., Nakaoka, S., Lauvset, S. K., Takahashi, T., Steinhoff, T., and Schuster, U.: A Surface Ocean $\mathrm{CO}_{2}$ Reference Network, SOCONET and Associated Marine Boundary Layer $\mathrm{CO}_{2}$ Measurements, Front. Mar. Sci., 6, 400, https://doi.org/10.3389/fmars.2019.00400, 2019.

Watson, A. J., Schuster, U., Bakker, D. C. E., Bates, N. R., Corbière, A., González-Dávila, M., Friedrich, T., Hauck, J., Heinze, C., Johannessen, T., Körtzinger, A., Metzl, N., Olafsson, J., Olsen, A., Oschlies, A., Padin, X. A., Pfeil, B., Santana-Casiano, J. M., Steinhoff, T., Telszewski, M., Rios, A. F., Wallace, D. W. R., and Wanninkhof, R.: Tracking the Variable North Atlantic Sink for Atmospheric $\mathrm{CO}_{2}$, Science, 326, 1391-1393, https://doi.org/10.1126/science.1177394, 2009.
Weiss, R. F. and Price, B. A.: Nitrous oxide solubility in water and seawater, Mar. Chem., 8, 347-359, https://doi.org/10.1016/03044203(80)90024-9, 1980.

Williams, N. L., Juranek, L. W., Feely, R. A., Johnson, K. S., Sarmiento, J. L., Talley, L. D., Dickson, A. G., Gray, A. R., Wanninkhof, R., Russell, J. L., Riser, S. C., and Takeshita, Y.: Calculating surface ocean $p \mathrm{CO}_{2}$ from biogeochemical Argo floats equipped with $\mathrm{pH}$ : An uncertainty analysis, Global Biogeochem. Cy., 31, 591-604, https://doi.org/10.1002/2016GB005541, 2017. 